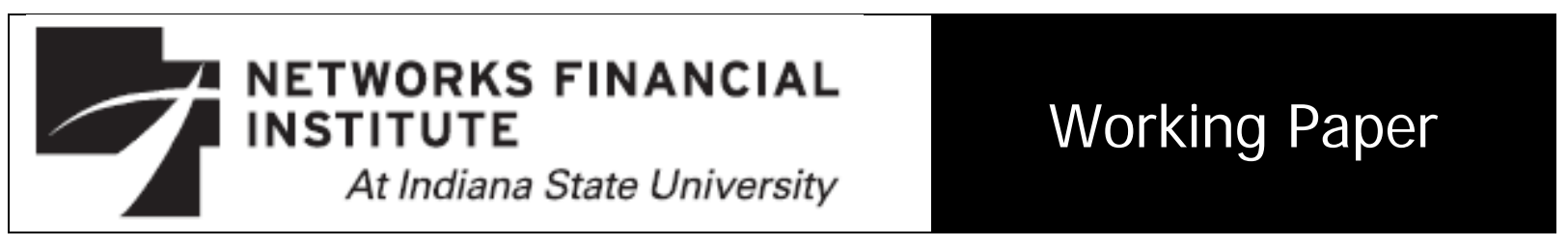

2017-WP-01

August 2017

\title{
Do Mergers and Acquisitions Affect I nformation Asymmetry in the Banking Sector?
}

\section{John S. Howe and Thibaut G. Morillon}

Abstract: We investigate the consequences of mergers and acquisitions (M\&As) for information asymmetry in the banking sector. We test competing hypotheses about the effect of M\&As on the information environment. M\&As either increase information asymmetry (the opacity hypothesis) or diminishes it (the transparency hypothesis). We find evidence that information asymmetry increases following $M \& A$ announcements and decreases following deal completions. These findings are more pronounced for acquisitions involving a private target, and all-cash deals, as well as for mergers as opposed to acquisition of assets. Additionally, we find that the enactment of Dodd-Frank reduced the levels of information asymmetry. The results are important to regulators, policy makers, and investors.

About the Authors: John S. Howe is Professor of Finance, Missouri Bankers Chair, and Chair of the Finance Department at the University of Missouri. He has been at MU more than two decades, with prior appointments at Louisiana State University and the University of Kansas. He earned his undergraduate degree (B.A.) from Colorado College and his graduate degrees (M.S., Ph.D.) from Purdue University. He is a Chartered Financial Analyst (CFA) as well as a Governance Fellow of the National Association of Corporate Directors. He serves on the boards of directors of several for-profit companies and has extensive non-profit board experience. Thibaut G. Morillon is a Ph.D. candidate and graduate assistant at the Robert J. Trulaske, Sr. College of Business at the University of Missouri. He was a financial advisor at LCL Retail Bank in Versailes, France.

Keyw ords: mergers and acquisitions, opacity hypothesis, transparency hypothesis, information asymmetry

\section{J EL classification: G34}

The views expressed are those of the individual author and do not necessarily reflect official positions of Networks Financial Institute. Please address questions regarding content to J ohn S. Howe at howej@missouri.edu. Any errors or omissions are the responsibility of the author.

NFI working papers and other publications are available on NFI's website (www. networksfinancialinstitute.org). Click on "Publications." 
We thank the Networks Financial Institute at Indiana State for funding for this project. Robert J. Trulaske, Sr. College of Business, University of Missouri, 401 Cornell Hall, Columbia, MO 65211

Robert J. Trulaske, Sr. College of Business, University of Missouri, 336 Cornell Hall, Columbia, MO 65211

\section{Introduction}

During the 1980s and 1990s, the U.S. banking industry experienced waves of mergers that changed the landscape of the industry and reduced the number of commercial banks. The trend of consolidation continued through the 2000s, with over 100 additional mergers occurring each year of the first decade of the $21^{\text {st }}$ century. ${ }^{1}$ The banking literature has focused on the causes of merger waves by looking at the underlying motivations of acquiring banks. It has also focused on the consequences of mergers, both in terms of performance efficiency as well as stockholder returns. However, few studies have paid attention to the potential improvement or deterioration of the information environment following mergers and acquisitions in the banking sector.

Our primary research question is whether the announcement of and the completion of mergers and acquisitions (M\&As) affect information asymmetry in the banking sector. On the one hand, the release of an important news regarding the future of a firm could reduce information asymmetry. Moreover, the increase in visibility generated by M\&As could attract more analysts and more investors, including institutional investors who might require more transparency. We refer to this scenario as the transparency hypothesis. On the other hand, the

\footnotetext{
${ }^{1}$ SHF financial database
} 
acquiring firm could become more risky, more complex, more complicated to manage and harder to evaluate, resulting in opacity. We refer to this scenario as the opacity hypothesis.

Past studies have looked at the impact of changes in the information environment following events such as the trading of private debt (Wittenberg-Moerman, 2008), dividend payouts (Kalay, 2014), change in credit rating (Brogaard et al., 2015), or asset write-offs (Haggard et al., 2015). However, none has looked at mergers and acquisitions (M\&As) in a comparable setting, a gap we aim to fill with this paper. M\&As qualify as events capable of sparking sudden changes in the information set available to investors. They are a natural laboratory in which to study the alteration of the information environment around specific keypoints of the acquisition process. The changing landscape of the banking sector as well as the constant attention it receives from regulators, policy makers and investors alike makes it an important setting for our investigation.

Our analysis covers over 3,100 mergers and acquisitions in the banking industry from 1980 to 2016. Following Haggard et al. (2015), we use ten different proxies for information asymmetry to examine banks’ information environment around M\&As, including return-based measures, spread-based measures, and liquidity-based measures.

Contrary to much M\&A research, we focus not only on the M\&A announcement but on the entire time span of the M\&A process. Specifically, we look at changes in information asymmetry taking place after the announcement of the merger as well as changes occurring after the merger is completed. We decompose the information environment into three subperiods: the period before the announcement of the merger (the pre-announcement period), the period between the announcement of the merger and its completion (the negotiation period), 
and the period following the completion of the deal (the post-completion period). Our study allows us to shed light on these three distinct periods during which we observe significant changes to the information environment.

We find mixed evidence around M\&A announcements. For all-cash deals and acquisition of private targets, our measures indicate a decrease in opacity following M\&A announcements. For all-stock deals and acquisitions involving public targets, the announcement does not have a significant impact. Additionally, our two liquidity measures sometimes point in different directions or indicate the opposite of the other measures. However, because both variables capture trading volume, we interpret these results as consistent with the conclusion of Chae (2005) that trading volume and information asymmetry can sometimes be completely unrelated, especially before non-recurring events.

We find evidence consistent with the transparency hypothesis in the post-completion period. Most notably, A sizeable majority of our information measures, including the liquiditybased measures, are consistent with the transparency hypothesis, indicating a decrease in opacity following merger completion.

The pattern described by our findings is consistent with a changing information environment, and show that information asymmetry is especially high during the negotiation period but decreases after the deal is completed. Thus, the "in-between” period is characterized by greater opacity. Moreover, we show that these results are driven by deals involving private targets, as the information environment appears to be affected to a lesser extent when the target is public. Finally, we also find evidence that the enactment of the Dodd-Frank Act reduced 
overall opacity significantly, and that differences in information asymmetry during the successive stages of the M\&A process disappear once the act was passed into law.

Our study contributes to the existing literature in at least four ways. First, we contribute to the merger and acquisition literature by showing that banks, on average, become more opaque following M\&A announcements and more transparent following M\&A completion. Where the literature traditionally focuses on M\&As’ consequences in terms of returns and performance, our study shows evidence of improvements of the information environment in the banking industry following the announcement of such events. Second, we decompose the merger process into three key periods and document that the period between the announcement of the merger and its completion is characterized by a more opaque environment. Third, we contribute to the information asymmetry literature by improving the understanding of the impact of a major corporate event on the information environment. We document changes around the announcement of an M\&A and the completion of the deal that are consistent with the view of corporate events acting as catalysts for change in the information environment. Finally, our findings suggest that Dodd-Frank reduced global level of information asymmetry as well as the magnitude of changes in information asymmetry around the announcement and the completion of a merger.

\section{Literature Review}

\subsection{Past Findings}

The successive waves of bank mergers in the 1980s and 1990s (see Figure 1) have been heavily scrutinized. The lifting of interstate regulation facilitated acquisitions in the banking sector, which over the years significantly reduced the number of commercial banks operating in 
the U.S. M\&As have been closely examined and discussed from multiple angles. From a motivation perspective, classic M\&A literature points to synergies resulting from an acquisition as the primary motivation for mergers. Multiple studies find that improvements can arise from better operational performance, a better use of the combined cash flows, tax savings, or more efficient management (Sudarsanam et al., 1996; Devos et al., 2009). The literature specific to the financial sector finds that synergies and diversification are the likely prime motivations for banks to undertake M\&As (Delong, 2001; Cornett et al., 2006).

Confronted with the finding that bidder claims of potential gains do not necessarily translate to significant observable improvements in performance (Piloff and Santomero, 1998; Berger et al., 1999), subsequent studies attempt to find other potential M\&A drivers. Brewer and Jagtiani (2007) find that the banks' desire to reach the status of "too big to fail” is another likely catalyst of the acquisition wave, as banks appear to be willing to pay a premium to realize acquisitions that would put them past a certain threshold.

Overall, the literature indicates that there might be additional incentives for banks to engage in M\&As beyond the traditional performance enhancement motives. Consequently, this multiplicity of potential drivers and incentives behind acquisitions points to the importance of information asymmetry between insiders (the negotiating parties) and outsiders (regulators, policy makers, and investors), an issue that we address in this paper.

Understanding the incentives behind a bank’s decision to make an acquisition leads to the question of which firms are likely to be bidders’ targets. Hagendorff (2012) finds that acquiring firms tend to aim for high-growth, low-risk targets as potential prospects for acquisition. Hernando et. al (2009) document that poorly managed institutions are more likely 
to be the target of bidders, especially if synergies can be found. Attracted by the potential gains, acquirers then often restructure portfolios and loan policies in order to be more profitable (Focarelli et al., 2002).

Performance is difficult to measure. Moller et al. (2004) find that smaller firms make significant gains around M\&A announcement as opposed to larger firms who, on average, see a significant decrease shareholder wealth. In a subsequent paper, Moller et al. (2005) find that mergers created value up until the mid-1990s, after which they became value-destroying. Dissecting returns on every deal, the authors conclude that if we exclude a few very large loss deals, mergers and acquisitions create shareholder value.

The consequences of M\&As in the banking sector are widely debated, both from a performance efficiency angle as well as from a shareholder value perspective. DeYoung et al. (2009) observe that the literature is mixed. Consistent with the hubris hypothesis (Roll, 1986), early studies of the U.S. market do not yield evidence of banking industry M\&As creating value (Houston and Ryngaert, 1994; Piloff and Santomero, 1998).

Yet subsequent literature finds that bank M\&As actually create shareholder wealth. Attempting to disentangle mergers’ consequences for both acquirer and target firms, Becher (2000) finds evidence that bank mergers in the 1990s created shareholder value. He shows that while acquiring firms break even, target firms usually witness large gains making the combined gain in value of the two firms positive. Houston et al. (2001) confirm these findings, showing that mergers slightly increase shareholder value if we combine the total value of the acquirer's and the target’s stock, a result they attribute to the prospect of cost savings. 
A similar pattern emerges regarding the performance efficiency of bank M\&As in that early studies find little or no gains of recently consolidated firms while recent studies document evidence of improvements (Berger and Humphrey, 1992; Linder and Crane, 1993; Rhoades, 1994). However, more recent studies showed that performance efficiency increases following U.S. M\&As (Cornett et al., 2006).

The banking literature documents other direct effects of M\&As in the banking sector. Amidst these effects, multiple studies find evidence that external stakeholders might be affected negatively by bank consolidation. They show that acquiring firms offer higher loan prices (Carrow, 2006), and overall are less competitive vis-à-vis its customers following mergers (Corvoisier, 2002). Francis et al. (2008) also find that new business formation suffers following large M\&As, especially in the short term, as larger consolidated banks tend to be more reluctant to supply credit to small business. Finally, recent studies show that following M\&As, the acquiring firms’ idiosyncratic risk decreases while their level of systematic risk increases, thus raising questions about bank consolidations’ destabilization potential, the “concentration-fragility” hypothesis (Weiß et al., 2014; Elyasiani et al., 2015).

\section{Hypothesis development}

We decompose the M\&A process into three distinct periods. First, the pre-announcement period consists of the 42 trading days before the announcement of a merger. Second, the negotiation period refers to the number of trading days between the announcement of a merger and its completion. Third, the post-completion period consists of the 42 trading days that follow the completion of a merger. 
We posit that the announcement and completion of M\&As act as catalysts of change in the information environment. There are two possible scenarios, the opacity hypothesis and the transparency hypothesis. On the one hand, the opacity hypothesis suggests that following the announcement (completion) of a merger, there is a degradation of the information environment. Indeed, M\&As are significant investments and as such, the firm might become harder to evaluate, more complex and more complicated to manage following such an operation. Consequently, it is likely that investors are going to have more divergence of opinion following the announcement (completion) of a deal.

On the other hand, the transparency hypothesis states that the quality of the information environment improves when managers reach each stage of the M\&A process. It argues that the release of new information is incorporated into the information set available to investors, and thus reduces information asymmetry. Additionally, the announcement or completion of investment deals such as M\&A is likely to increase visibility as well as investors' and analysts' scrutiny, which in turn might result in a decrease in opacity.

It is important to note that the two hypotheses are not mutually exclusive. It is possible that firms experience different or even opposite reactions following the announcement and the completion of a deal. In fact, our primary hypothesis is that of a decrease of the quality of the information environment following the announcement of a merger as it implies more uncertainty, and is likely to generate more differences of opinion. However, we posit that the information environment is more transparent following the completion of the deal, as it reduces speculation and divergence of opinion about the likelihood of completion of the operation. These lines of reasoning lead to our first two hypotheses. 
H1: No effect: the announcement of a merger has no effect on the information environment.

H1a: Opacity hypothesis: the announcement of a merger increases opacity.

H1b: Transparency hypothesis: the announcement of a merger decreases opacity.

H2: No effect: the completion of a merger has no effect on the information environment.

H2a: Opacity hypothesis: the completion of a merger increases opacity.

H2b: Transparency hypothesis: the completion of a merger decreases opacity.

Our next hypothesis focuses on the differences that are likely to emerge between deals involving public targets versus deals involving private targets. We conjecture that it is costlier to acquire information regarding private firms and as such, it is likely there will be a greater disparity of information quality and opinion for acquisitions involving private targets compared to public targets, for which information is more easily accessible. Consequently, the magnitude of the change in the quality of the information environment around every stage of the M\&A process is greater when the target is private. An alternative hypothesis is that there is simply no difference between the acquisition of public and private targets.

H3: The information environment in affected similarly independently of the nature of the target firm.

H3a: The magnitude of the changes in the information environment is greater when the target is private.

Our fourth hypothesis concerns the nature of the deal. We contend that the impact on the information environment is different between mergers and acquisitions of assets. Indeed, firms involved in a merger create a new entity with a new ownership and management structure. As such, we posit that there might be more uncertainty regarding the operation than there is for an 
acquisition, in which the target firm simply cease to exist while its assets are acquired and absorbed by the bidder. An alternative hypothesis is that there is no difference between the two types of deals.

H4: The magnitude of the changes to the information environment is similar for mergers and acquisitions.

H4a: The magnitude of the changes to the information environment is weaker for acquisition of assets as opposed to mergers.

Our next hypothesis concerns the method of payment. We look at the information environment around all-cash deals and all-stock deals to determine whether the method of payment impacts it differently. One possibility is that offers involving stock are more complex and harder to evaluate. Valuation is a prime concern in M\&A and as such, this reasoning suggests that the change in the information environment is greater for all-stock deals than for all-cash deals.

An alternative hypothesis relies on past literature that shows that the outcome of a merger is affected by the method of payment. All-stock deals' returns tend to be more consistently negative and less volatile than that of all-cash deals (Eckbo, 2008). Additionally, Officer et al. (2008) explain that stock offers are a way for the bidder to share overvaluation risks with the target and as such, make M\&A deals less risky for the acquirer, especially when the target is hard to evaluate. All-cash deals on the other hand are riskier as they expose the bidder to potential target overvaluation. Consequently, this theory suggests that the magnitude of the changes to the information environment is likely to be greater for all-cash deals. A third possibility is that there is simply no difference between all-cash and all-stock M\&As. 
H5: The method of payment has no effect on the magnitude of the changes to the information environment.

H5a: The magnitude of the changes to the information environment is greater for all-cash deals.

H5b: The magnitude of the changes to the information environment is lower for all-cash deals.

Finally, our last hypothesis regards the impact of the Dodd-Frank Act, enacted on July $21^{\text {st }}$, 2010. The Act aimed at making the banking system safer through several rulings and provisions. It was structured around several core principles, including reducing information asymmetry through a reduction of the ability of commercial banks to take risks, and an increase and regulation of public disclosures "in order to support market evaluation of the risk profile, capital adequacy, and risk management capabilities”.2

We want to investigate whether the Dodd-Frank Act accomplished this objective and affected the quality of the information environment. If it did, the magnitude of the changes in the information environment around the two stages of the M\&A process should be reduced significantly, and the overall level of opacity should decrease. An alternative hypothesis is that the Act did not affect the information environment and that the magnitude of the changes following the announcement or the completion of a merger were not or very little affected.

H6: The information environment is unaffected by Dodd-Frank, and the magnitude of the changes following the announcement or the completion of a deal are unchanged after the passage of the law.

${ }^{2}$ https://www.sec.gov/about/laws/wallstreetreform-cpa.pdf 
H6a: The information environment becomes less opaque after Dodd-Frank, and the magnitude of the changes following the announcement or the completion of a deal is decreased after the passage of the law.

\section{Data and empirical methods}

\subsection{Data}

From SDC, we obtain the list of all the completed domestic mergers and acquisitions in the banking sector from 1980 to 2016. Following Moller et al., (2005), we apply the following filters:

(1) The acquirer and the target are domestic firms.

(2) The acquirer is a public firm.

(3) The deal is completed and worth at least $\$ 1$ million in value.

(4) The acquirer owns less than $50 \%$ of the target's shares before the merger ex-ante.

(5) The acquirer owns $100 \%$ of the target's shares after the merger.

We then merge the dataset with Compustat as we need information on banks' fundamentals. Following the empirical approach of Haggard et al. (2015), we control for size (total assets), book-to-market ratio, debt-to-equity ratio and income scaled by lagged. We only keep deals involving commercial banks; that is, we filter out acquirers and targets whose Compustat primary SIC code is not between 6020 and 6030 (commercial banks). Then we keep deals for which we are able to obtain daily stock price data from CRSP. This set of constraints yields a total of 3,146 deals over the span of our sample. Figure 1 displays the distribution of the mergers in our sample over the years. We see that there are some periods of intense 
consolidation of the banking industry, especially during the 1990s. In the robustness section, we show that our results are robust to the various "merger waves".

\subsection{Empirical methods}

To run our tests, we use firm-day observations for each bank in our sample. The firms’ fundamentals are updated annually, so we use the reported December year-end information in year t-1 to calculate firms' fundamentals for the full year. Each information asymmetry proxy requires its own set of information and variables to compute. Consequently, our regressions do not have the same number of observations.

To investigate the evolution of the information environment during M\&As, we split the process into three distinct periods as displayed in Figure 2. Consistent with the work of Schwert (1996) and Betton et al. (2008) on M\&A run-up period, we define the preannouncement period as the 42 trading days prior to the announcement date of the deal. The post-completion period consists of the 42 trading days after the date the merger is effective. The negotiation period is the transition period that separates the date the merger is announced from the date the merger is effective. When the announcement date or the date effective occurs in a non-trading day, we consider the next trading day as the cutoff for the relevant period to make sure our results are consistent with the market’s learning process.

We create indicator variables that capture the variation in information asymmetry over our three periods of interest. Pre-Announcement is an indicator variable equal to one if the observation is recorded before the M\&A announcement, zero otherwise. Post-Completion is an

indicator variable equal to one if the observation is recorded after the M\&A date effective, zero 
otherwise. In our tests, the coefficients indicate the change in information asymmetry with the negotiation period as the point of reference.

\subsection{Information asymmetry}

We investigate the effect of M\&As on the information environment by looking at a series of 10 different information asymmetry measures (IAMs). For data constraint reasons, we are not able to recreate all 11 IAMs from Haggard et al. (2015), particularly spread-based measures. ${ }^{3}$ Consequently, we use data available from CRSP to create three spread-based variables in accordance with Chordia et al., (2000). ${ }^{4}$ We calculate our 10 market-based measures using data from the CRSP daily file using a window of 42 trading days before the announcement date to 42 trading days after the completion date. We use return-based measures as well as spread-based measures and liquidity-based measures.

We use two liquidity-based measures: Turnover is defined as the monthly volume divided by shares outstanding. For ease of interpretation, we the turnover ratio by -1 so that it measures stock illiquidity instead of stock liquidity. This approach is consistent with the purpose of our study as greater illiquidity implies more information asymmetry. Amihud is the log of the ratio of the daily dollar volume price impact, defined as the absolute value of daily return divided by daily dollar volume, calculated in accordance with Amihud (2002).

\footnotetext{
${ }^{3}$ Haggard et al. (2015) use 11 information asymmetry measures including I/B/E/S based analyst data. Analyst data is not as meaningful when observing changes on a daily basis as opposed to a monthly basis. Additionally, Haggard et al. use Quoted Spread and Effective Spread as two spread measures calculated via the TAQ database. We do not have access to the TAQ database. As such, we replace these measures with spread-based measures from Chordia et al., (2000) using available CRSP data.

${ }^{4}$ We create PQ Spread, Effective Spread and PE Spread from Chordia et al. (2000) using available CRSP data.
} 
We use six different spread-based variables. We calculate Daily Spread as the daily difference between the day’s high and low trading prices divided by the closing price. HL Spread is the daily estimated effective spread calculated in accordance with Corwin and Shultz (2012). Roll is estimated as the daily covariance in prices calculated in accordance with Roll (1984). PQ Spread is computed as the difference between the closing ask and bid prices divided by the closing bid-ask midpoint. Effective Spread is calculated as twice the absolute value of the price minus the bid-ask midpoint. PE Spread is computed as twice the absolute value of the price minus the bid-ask midpoint scaled by price. PQ Spread, Effective Spread and PE Spread are calculated in accordance with Chordia et al., (2000).

Finally, our set of variables includes two return-based variables. Realized Volatility is the sum of squared daily returns while Standard Deviation is the standard deviation of daily returns per period (the pre-announcement period, the negotiation period, and the post-completion period) scaled by a factor of 100. As such, Standard Deviation has fewer observations than other computed variables because we use firm-days observations over each of the three periods to calculate the standard deviation of the returns.

\subsection{Summary statistics}

Table 1 provides details on our sample as well as summary statistics for our information asymmetry measures (IAMs) and control variables. To mitigate the impact of outliers, we winsorize IAMs and control variables at the one percent level, in conformity with past literature. Panel A breaks down the composition of our sample. Our sample comprises 3,146 deals representing 651,123 individual firm-day observations. We note that there are 582 individual acquirers, indicating the presence of serial acquirers. Overlapping acquisitions can 
be problematic from an econometric standpoint. We address the serial acquirer concern in the robustness section by showing that our results are qualitatively similar when we remove overlapping acquisitions from the sample.

Panel B reports the characteristics of the deals in our sample. Our sample is roughly split in half between private target and public targets, each representing over $45 \%$ of the sample. Targets that are subsidiaries represent about $9 \%$ of the sample. A large majority of the deals are mergers (86.08\%) while the remaining $13.92 \%$ are acquisitions. The overwhelming majority of the deals in our sample are friendly M\&As, and only $1 \%$ of the deals are hostile in nature. ${ }^{5}$ The acquisitions in our sample also vary in the method of payment. Approximately $47 \%$ of the M\&As are all stock-deals, $15 \%$ are all-cash deals, while the remaining acquisitions are paid for with a mix of cash and stock.

Panel C presents sample summary statistics about the firms in our sample. The average bank engaging in an M\&A is worth slightly over $\$ 24$ billion. The median size of $\$ 4.6$ billion and the high standard deviation suggests that some large entities have been M\&A-active, driving the average size up. The average book to market ratio is 0.675 , indicating that M\&Aactive banks tend to be highly valued by the market. The average debt to equity ratio is 1.718 , with a median value of 1.407 , while the average bank's income is about $1.2 \%$ of its lagged assets. The standard deviation of these control measure suggests that there is variety in the profile of acquiring banks. Panel C also reports the mean, median, and standard deviation of our eight primary measures of information asymmetry. The number of observations per

\footnotetext{
${ }^{5}$ We consider as hostile any deal reported as hostile or neutral by SDC.
} 
measure varies as they are computed using components that are missing in some cases.

Standard Deviation has fewer observations than other variables because we use firm-day observations over each of the three periods of interest to calculate the standard deviation of the returns.

The statistics are consistent with past literature. For example, the sample in Chordia et al. (2000) sample has a mean (median) PQ Spread value of 0.016 (0.011) and a mean (median) Effective Spread of 0.225 (0.179), consistent with our corresponding mean (median) values of $0.015(0.09)$ and $0.242(0.125)$.

\section{Results}

\subsection{M\&A process}

Following Haggard et al. (2015), we structure our tests to identify change in information asymmetry following M\&As, after controlling for variables likely to influence changes in the information environment. We run a regression with each of our IAMs on two indicator variables as well as our set of control variables (the coefficients are reported as percentage changes). Pre-Announcement captures changes occurring before the date of announcement of the deal. Post-Completion captures the changes occurring after the date the deal is officially effective. Therefore, the coefficients capture the change in information asymmetry between the period observed and the negotiation period (see Figure 2). Moreover, we calculate the variables such that a positive coefficient implies an increase in information asymmetry from one period to the next, while a negative coefficient implies a decrease in information asymmetry. To alleviate the concerns about the nature of the variation captured by our indicator variables, we cluster standard errors by firm and year-month. 
Table 2 reports the results of our setting for the full sample (for clarity's sake, we do not report the coefficients of control variables). Overall, we find evidence consistent with both the opacity and the transparency hypothesis. The negotiation period is characterized by high levels of opacity.

Evidence regarding the pre-announcement period is mixed. All eight spread-based and return-based variables have a negative point estimate, but only PE Spread and Return Std are statistically significant (the negative coefficients mean that information asymmetry is lower during the pre-announcement period and therefore higher in the negotiation period). However, we observe that the liquidity-based variables point in a different direction. Trading volume is a key component of both Turnover and Amihud and as such, these proxies capture information related with trading behavior. This dichotomy is consistent with Chae (2005) who finds that trading volume is negatively correlated with information asymmetry before earnings announcements, but shows no correlation with information asymmetry proxies for unscheduled events. M\&As are prime examples of unscheduled events and as such, we interpret this finding as consistent with Chae's work.

Overall, these results offer modest evidence that opacity increases following the announcement of a merger as investors opinions about the prospects of the firm are likely to be more scattered following a merger announcement.

Results regarding the post-completion period are less ambiguous as almost all the IAMs point towards a reduction in opacity following the completion of a merger (only Realized Volatility significantly points in the opposite direction). Importantly, the liquidity-based and 
spread-based measures significantly point in the direction of a decrease in information asymmetry following the completion of the deal (with the exception of HL Spread).

For example, Turnover, PE Spread and PQ Spread, decrease by 2.4, 4.3, and 10.1 basis points in the post-completion period compared to the negotiation period. The magnitude of these changes is economically significant, and this pattern is consistent with the findings of Haggard et al. (2015) who conclude that information asymmetry levels decline following accounting baths.

Overall, our results suggest that the post-completion period of a merger is less opaque, but also more liquid than the negotiation period. In other words, there is a decrease in information asymmetry following the completion of a merger.

There are several reasons why we see such a pattern throughout the M\&A process. First, Merton (1987) shows that larger firm size suggests greater visibility. By acquiring some of their peers, banks grow in size, thus becoming more visible which in turn induces a higher volume of trade, more scrutiny, and a decrease in information asymmetry. In addition, M\&As are likely to induce portfolio rebalancing, which could explain an increase in trading volume. As pointed out earlier, trading volume is a common component of the two liquidity measures and is likely driving those results. This explanation suggests that the increase in size and visibility is the primary driver of the liquidity-based measures.

Chae (2005) interprets her results as consistent with theories of asymmetric information in which discretionary liquidity traders are more reluctant to trade when adverse selection costs are high, implying less liquidity before an announcement and more liquidity afterwards. M\&As 
are particular events due to the multiple stages of the process, but our findings appear consistent with that interpretation.

Another possibility is that informed traders take advantage of an environment with more information asymmetry to exploit their private information (Kyle, 1985). In the context of M\&As, the increase in information asymmetry following the announcement of the merger represents an opportunity for informed traders to trade on their private information, thus explaining the negative relationship between trading volume and information asymmetry.

Overall, our results are consistent with the opacity hypothesis following the announcement of a merger, and the transparency hypothesis following its completion. We attribute the behavior of the liquidity-based measures in the pre-announcement period as consistent with Chae (2005), and the remaining measures point in the same direction. This conclusion suggests that the negotiation period, which is specific to the M\&A, is the most opaque period of the takeover process.

\subsection{Target Status}

We now look at whether the evolution of the information environment during the M\&A process is affected by the status of the target. The information available to investors is likely to be affected by the ownership status of the target as well as its relation to the acquirer. To investigate this possibility, we decompose our sample into three subsamples: one with public targets exclusively, one we private targets only, and one comprising only subsidiaries.

Panel A of Table 3 reports the results of our regression setting for the public target subsample. Overall, the direction and magnitude of all the coefficients is comparable to that of the full sample for the Post-Completion indicator variable, although slightly lower in terms of both 
magnitude and statistical significance. However, we note two main differences regarding the Pre-Announcement indicators variables. First, the results are in general much less significant than for the full sample. This pattern is particularly obvious for the spread-based and returnbased variables, which yield inconsistent point estimates, of which none are statistically significant. Second, the two liquidity-based measures are now positive, and we note that the magnitude of turnover is roughly four times as big as in the full sample, which likely reflects a lower trading volume in the 42 days leading up to the announcement of a merger.

These results suggest that for M\&As involving public targets, there is little evidence of a change in the information environment following the announcement of a merger. This result might be because public firms are more visible, with information more easily accessible to investors and as a consequence, we do not observe a significant change in the IAMs. The postcompletion period is similar to that of the full sample with an apparent decrease in opacity across the board once the merger is effective, consistent with divergence of opinion regarding the likelihood of completion of a merger during the negotiation period.

Panel B presents the results for the private target subsample. The coefficients of the PreAnnouncement indicator variable are all negative. Seven out of ten are statistically significant, with a much greater magnitude than in the two previous samples. It appears that much of the increase in opacity following the announcement of a merger comes from mergers involving a private target. The results imply a difference in the way the information environment is affected by the announcement of an M\&A, depending on whether the target is public or private. This finding confirms our initial hypothesis, as it is by definition costlier to acquire information on private firms and as such, the information environment is more opaque following the 
announcement of the acquisition of a private target as differences of opinions between investors are likely to be magnified in those circumstances. Moreover, we note that the two liquiditybased variables are now consistent with the remaining IAMs, meaning that inverse relationship between liquidity and information asymmetry does not apply to our sample of private targets.

The results for the post-completion period are analogous. Nine out of ten IAMs indicate a material decrease in opacity following the completion of a merger involving a private target. The spread-based variables are all significant, some with a magnitude about twice as large as that of the public sample. To illustrate, daily Turnover decreases by 2.9 basis points, daily $P E$ Spread decreases by 6.7 basis points and daily HL Spread is lower by 4.8 basis points. These are significant decreases given their respective means of $0.24 \%, 0.94 \%$ and $0.92 \%$. Realized Volatility is the only insignificant variable, although we note that it was significant in the opposite direction in the other samples.

Panel C reports the results for the sample with only targets that are subsidiaries of the acquirer. The subsidiaries of our sample are by definition firms whose voting rights are controlled by a parent firm (the acquirer). The results are consistent with our initial hypothesis in that the change in the level of information asymmetry is much milder or non-existent for the subsidiaries sample. Indeed, almost all the coefficients of the pre-announcement indicator variable are statistically indifferent from zero. The only two significant IAMs are Amihud and Realized Volatility, both of which go in the opposite direction to that of the other samples.

The lack of effect is even more obvious in the post-completion period where no IAM except Turnover is statistically significant. We interpret these results as consistent with the notion that there is less uncertainty when acquirers target firms that are already their 
subsidiaries, hence a lack of change in the information environment around both stages of the M\&A process.

Overall, our findings suggest that M\&As involving private targets are strongly associated with opaque environments. Although we observe a similar pattern for deals involving public targets, the magnitude of the change is stronger when the target is private, and is particularly obvious around the announcement of the deal. We conclude that the information environment surrounding acquirers is affected differently depending on the status of the target they are looking to acquire, as evidenced by the lack of reaction when the target is a subsidiary of the acquirer. Moreover, we find that liquidity-based variables are uncorrelated to other information asymmetry proxies in the pre-announcement period only for deals involving public targets.

\subsection{Merger vs. acquisitions}

We next test whether the type of deal observed affects the information environment. Firms involved in a merger create a new entity with a new ownership and management structure. As such, we posit that there might be more uncertainty regarding the operation than there is for an acquisition, in which the target firm simply ceases to exist while its assets are acquired and absorbed by the bidder.

Panel A of Table 4 reports what types of firms are involved in both types of operation. The merger sample resembles the full sample; every type of firms is proportionately represented, except for subsidiaries which are underrepresented. This pattern is reversed in the acquisition sample as subsidiaries represent almost half of the sample, with only $3 \%$ of public firms. In other words, a high proportion of acquisitions is subsidiaries being fully absorbed by their parent company. As such, on one hand we expect the acquisition sample to present 
characteristics similar to that of the subsidiary sample, with a smaller reaction of the market to the M\&A process. On the other hand, we expect the merger sample to be similar to the global sample.

Panel B reports the coefficient of our OLS setting for the sample of merger deals. As expected, the coefficients for both the Pre-Announcement as well as the Post-Completion indicators are very similar to that of the global sample, both in terms of magnitude as well as in terms of statistical significance. We note that Return Std is significant in the pre-announcement period and that at least one IAM of every category is significant in both periods. The results are thus consistent with the findings of the overall sample, including the apparent lack of correlation between liquidity-based variables and the rest of the IAMs.

Panel C reports the results for the sample containing only acquisitions. Consistent with our prediction, there is only very weak evidence of any impact of the M\&A process on the information environment. In the post-completion period, the IAMs appear to be capturing some variation, although they do not all point in the same direction. Overall, we interpret these results as consistent with our prediction that acquisitions affect the information environment much less than mergers, and that this effect is mainly driven by subsidiaries.

\subsection{Deal Nature}

We now investigate whether deal nature affects the information environment. To do so, we look at hostile deals to determine if the change in information environment exhibits a different pattern than it does for friendly deals. Because there are so few hostile deals (a total of 33 in our sample), Table 5 reports only the result of our regression for hostile deals as the 
remainder of our full sample is by definition friendly. We find that the pattern of the change in the information environment induced by hostile is opposite to that of the rest of the deals.

Indeed, almost all the IAMs point in the opposite direction to that of the full sample. The information environment appears particularly opaque in the run-up period, as almost all proxies are significant and positive. We observe the same dichotomy between Turnover and the rest of the IAMs. This finding can be interpreted as consistent with theories of investors with private information trading on their knowledge. Indeed, hostile deals are generally associated with reduction in the bidder's stock price (Schwert, 2000). Consequently, it can be an opportunity for informed trader to make a profit using their private information. The coefficients of the Post-Completion indicator variable tell a similar story, as seven out of 10 are positive and significant. The transition period of hostile deals thus appears to be less opaque, which contrasts with our findings for the remainder of the sample.

There are two caveats. First, there are only very few hostile deals in our sample. Moreover, some deals start out as hostile and end up being branded as friendly. As such, the data we use, as reported by SDC, might not fully reflect the full extent of hostile deals.

\subsection{Method of payment}

We now look at whether the choice of the method of payment affects the information environment. To do so, we specifically look at the all-stock deals and the all-cash deals of our sample. Panel A of Table 6 reports the results of our regression setting for the all-stock deals of our sample, which account for roughly $47 \%$ of the sample. The most important finding is that there appears to be little to no change induced by the announcement of an all-stock deal. 
Only two IAMs are significant, pointing different directions. The remaining measures are indistinguishable from zero.

Past literature suggests different mechanisms provide an explanation for this finding. First, this pattern is consistent with the hypothesis that there is less variation of opinion around all-stock deals because they are overall more likely to generate low or negative abnormal returns (Eckbo 2008). Additionally, all-stock offers are seen as less risky for the bidder, especially when acquiring volatile targets (Officer et al., 2008), as it allows the acquirer to share overvaluation risk with the target. Indeed, overvaluation is one of the principal risks associated with M\&As (Rhodes-Kropf, 2004). Consequently, an all-stock acquisition is riskreducing (from the bidder’s perspective), especially when the target is hard to value.

Another explanation is that there might simply be fewer private firms engaging in allstock deals. In untabulated tests, we investigate this possibility by looking at the number of private and public firms in each of the all-stock and all-cash sample. There are indeed more public firms in the all-stock sample (roughly 56\%), but the difference is not extreme. Moreover, $18 \%$ of the all-cash sample comprises subsidiaries versus only 3\% for the all-stock sample. We conclude that the pattern observed is more consistent with the risk-sharing hypothesis than the likelihood that a given type of firm in the sample is driving our results.

The post-completion coefficients are similar to that of the full sample, with some evidence of a decrease in opacity following deal completion, as six out of 10 IAMSs significantly point towards that direction. Overall, results for all-stock deals indicate that the announcement of a deal paid for with only equity has little influence on the information 
environment, but that the conclusion of such a deal does. This result is consistent with a less opaque post-completion environment.

Panel B presents the results of our setting for all-cash deals. All-cash deals are less common and represent about $15 \%$ of our sample. The coefficients on the Pre-Announcement indicator variable suggests that the information environment becomes more opaque following the announcement of an all-cash deal, as the spread-based and return-based variables point in that direction (with the exception of $P Q$ Spread). The liquidity-based variables present the same dichotomous behavior we identified in some of the previous samples, as they go in the direction opposite to that indicated by other IAMs (although once again, only Turnover is significant). This pattern further confirms Chae's (2005) findings that there are cases of unscheduled events where information asymmetry and liquidity are uncorrelated.

The post-completion period is characterized by an decrease in the level of opacity similar to that observed in the full sample. However, one exception consists of the behavior of the liquidity-based variables, which are not significant. It appears that although there is some evidence of change in the levels of information asymmetry during the acquisition process of an all-cash deal, liquidity is unaffected.

We conclude that the method of payment of a deal affects the magnitude of the changes in the information environment around key stages of the takeover process. On the one hand, allcash deals seem to affect the levels of information asymmetry around both the announcement date and the competition date, making the transition period a particularly opaque time period of the M\&A process. On the other hand, all-stock deals appear to affect the information 
environment mostly around the conclusion of the deal, as we seldom find evidence of any change around the announcement of these operations.

\subsection{Impact of the Dodd-Frank Act}

We now look at whether the Dodd-Frank Act enacted on July $21^{\text {st }} 2010$ had any effect on the information environment and the impact of changes in information asymmetry during the M\&A process. To investigate the question, we create an indicator variable Dodd-Frank equal to one if a firm-year observation occurs after the enactment of the Act, zero otherwise, and interact it with our existing indicator variables for the Pre-Announcement and the PostCompletion periods.

Table 7 reports the coefficients of the regression. We note that the coefficients on the initial indicator variables are consistent with our earlier findings, although some IAMs lose significance for the pre-announcement period pre-Dodd-Frank. The coefficients on our indicator variable for the enactment of Dodd-Frank are uniformly negative and significant. This pattern suggests that the passage of the law reduced information asymmetry, independent of the M\&A period we are looking at. Furthermore, we note that the magnitude of the reported changes is economically important. For example, Turnover decreases by 19.7 basis points and HL Spread decreases by 33.4 basis points, a significant decrease given their sample means of 24 basis point and 92 basis points.

The F-tests on the two furthermost right columns test whether we see a change in the information environment following the announcement period and the completion period respectively, after the passage of Dodd-Frank. The two liquidity-based IAMs, Turnover and Amihud are significant, indicating that we still see changes in the levels of information 
asymmetry around the two stages of the M\&A process. For the remaining variables, every Ftest is insignificant. We interpret this result as evidence that the enactment of Dodd-Frank not only reduced the levels of information asymmetry in general, but also reduced the magnitude of the changes in information asymmetry levels during the M\&A process. In other words, following Dodd-Frank, the evidence of an increase (decrease) in opacity following the announcement (completion) of the deal weakens or disappears completely. This result provides evidence that the enactment of Dodd-Frank coincided with a reduction in the level of opacity around commercial banks acquisitions.

\section{ROBUSTNESS}

\subsection{Window of observation}

The size of the window of observation determines how far back (and forward) we go to analyze the changes in the information environment. In our baseline regressions, we use a window of 42 trading days before the announcement date as it is commonly referred to in the M\&A announcement return literature as the length of the "run-up" period, and 42 trading days after the effective date in order to have a balanced setting (see, Betton et al., 2009). To confirm that our results are not just the product of a specific window frame, we conduct our tests over different time windows (+/-60 days, $+/-25$ days). In untabulated results, we find that our results are robust to such changes.

It is possible to consider longer windows of observation, but this approach comes with additional concerns. First, we have to make sure we are capturing change in the information environment, and longer periods run the risk of being influence by other events. Moreover, the 
cases of firms with multiple overlapping transactions might become problematic. We deal with this possibility in the next section.

\subsection{Serial acquirers}

Serial acquirers are firms that complete multiple bids within a defined period. Past literature has used different criteria to define what it means to be a "serial acquirer”. For example, Fuller et. al. (2002) define as serial acquirers firms that acquire five or more firms within a three-year window. Lamanen and Keil (2008) include any firm that made at least four acquisitions in 10 years as their definition of serial acquirers, and Aktas et al. (2008) consider any firm that makes at least two acquisitions within a span of 12 months to be a serial acquirer.

A potential problem consists of firms that make subsequent acquisitions in a manner that creates overlapping time periods for two (or more) M\&As. To alleviate that concern, we re-run our series of tests by eliminating any overlapping acquisition and keep only "uncontaminated" observations. The length of the window used to define the announcement period and the postcompletion period affects the number of observations, but our results remain qualitatively similar for all time windows, although the evidence for the pre-announcement period is weaker across the board.

\subsection{Merger waves}

Another concern could be that merger waves might affect our results. To alleviate that concern, we run our tests controlling for the different merger waves with indicator variables. In different specifications, we control for the merger waves as defined in previous literature (Betton et al., 2007) or by controlling for the years of our sample with the largest number of M\&As. Our (untabulated) results are qualitatively similar with the addition of these controls 


\section{CONCLUSION}

This paper examines changes in the information environment associated with M\&As in the banking sector in the banking sector. Examining 3,146 M\&As between 1980 to 2016, we find evidence to support the opacity hypothesis following the announcement of a merger, and the transparency hypothesis following the completion of a merger. Using a series of 10 measures of information asymmetry, we find evidence consistent with a degradation (improvement) of the information environment in the negotiation period (post-completion period) when compared to the pre-announcement period (negotiation period). We find evidence that this pattern is especially pronounced for mergers as opposed to acquisitions, all-cash deals, and M\&As involving a private target. Conversely, the information environment is very weakly influenced by acquisitions of subsidiaries. Moreover, information asymmetry levels do not change very much when an all-stock deal, or the acquisition of a public target is announced. We document a dichotomy between the behavior of liquidity-based measures and the rest of our information asymmetry measures in some circumstances, which is consistent with Chae's (2005) findings.

Finally, we find evidence suggesting that the passage of the Dodd-Frank Act contributed to reduce opacity in the information environment. We find that following the enactment of the law, changes in the information environment following the announcement or the completion of the merger are much milder than before. Moreover, the passage of the law itself seem to have decreased overall levels of information asymmetry. 


\section{References}

Aboody, David, and Baruch Lev. "Information asymmetry, R\&D, and insider gains." The Journal of Finance 55, no. 6 (2000): 2747-2766.

Altunbaş, Yener, and David Marqués. "Mergers and Acquisitions and Bank Performance in Europe: The Role of Strategic Similarities." Journal of Economics and Business 60, no. 30 (2008): 204-22

Al-Khasawneh, Jamal Ali, and Naceur Essaddam. "Market Reaction to the Merger Announcements of US Banks: A Non-parametric X-efficiency Framework." Global Finance Journal 23, no. 3 (2012): 167-83

Al-Sharkas, Adel A., and M. Kabir Hassan. "New Evidence on Shareholder Wealth Effects in Bank Mergers during 1980-2000." Journal of Economics and Finance 34, no. 3 (2010): 326-48.

Atiase, Rowland K., and Linda Smith Bamber. "Trading volume reactions to annual accounting earnings announcements: The incremental role of predisclosure information asymmetry." Journal of Accounting and Economics 17.3 (1994): 309-329.

Becher, David A. "The Valuation Effects of Bank Mergers." Journal of Corporate Finance 6, no. 2 (2000): 189-214.

Berger, Allen N., and David B. Humphrey. "Megamergers in banking and the use of cost efficiency as an antitrust defense." Antitrust Bull. 37 (1992): 541.

Berger, Allen N., Rebecca S. Demsetz, and Philip E. Strahan. "The consolidation of the financial services industry: Causes, consequences, and implications for the future." Journal of Banking \& Finance 23, no. 2 (1999): 135-194.

Betton, S., E. Eckbo, and K. Thorburn. "Takeovers, restructurings, and corporate control." Handbook of Corporate Finance: Empirical Corporate Finance 2 (2007).

Betton, S., B. E. Eckbo and K. S. Thorburn, 2008b, “Markup Pricing Revisited,” Working Paper, Tuck School of Business at Dartmouth.

Betton, Sandra, B. Espen Eckbo, and Karin S. Thorburn. "Merger negotiations and the toehold puzzle." Journal of Financial Economics 91, no. 2 (2009): 158-178.

Brewer, Elijah, and Julapa Jagtiani. How Much Would Banks Be Willing to Pay to Become "toobig-to-fail" and to Capture Other Benefits? Kansas City [Mo.: Research Division, Federal Reserve Bank of Kansas City, 2007.

Botosan, Christine A. "Disclosure level and the cost of equity capital." Accounting Review (1997): 323-349. 
Brogaard, Jonathan, Jennifer L. Koski, and Andrew F. Siegel. "The Information Content of Credit Rating Changes: Evidence from Trading Volume." Available at SSRN 2619522 (2015).

Carow, Kenneth, Edward Kane, and Rajesh Narayanan. "How Have Borrowers Fared in Banking Mega-Mergers?" NBER Working Paper 10623 (2003).

Chae, Joon. "Trading volume, information asymmetry, and timing information." The Journal of Finance 60, no. 1 (2005): 413-442.

Core, John E. "A review of the empirical disclosure literature: discussion." Journal of Accounting and Economics 31, no. 1 (2001): 441-456.

Cornett, Marcia Millon, Jamie John Mcnutt, and Hassan Tehranian. "Performance Changes Around Bank Mergers: Revenue Enhancements versus Cost Reductions." Journal of Money, Credit, and Banking 38, no. 4 (2006): 1013-050.

Corvoisier, Sandrine, and Reint Gropp. "Bank Concentration and Retail Interest Rates." Journal of Banking \& Finance 26 (2002): 2155-189.

Cybo-Ottone, Alberto, and Maurizio Murgia. "Mergers and shareholder wealth in European banking." Journal of Banking \& Finance 24, no. 6 (2000): 831-859.

Delong, Gayle L. "Stockholder Gains from Focusing versus Diversifying Bank Mergers." Journal of Financial Economics 59, no. 2 (2001): 221-52.

Devos, Erik, Palani-Rajan Kadapakkam, and Srinivasan Krishnamurthy. "How do mergers create value? A comparison of taxes, market power, and efficiency improvements as explanations for synergies." Review of Financial Studies 22, no. 3 (2009): 1179-1211.

Deyoung, Robert, Douglas D. Evanoff, and Philip Molyneux. "Mergers and Acquisitions of Financial Institutions: A Review of the Post-2000 Literature." Journal of Financial Services Research 36, no. 2-3 (2009): 87-110.

Draper, Paul, and Krishna Paudyal. "Information asymmetry and bidders' gains." Journal of Business Finance \& Accounting 35, no. 3-4 (2008): 376-405.

Easley, David, Soeren Hvidkjaer, and Maureen O’Hara. "Is information risk a determinant of asset returns?" The Journal of Finance 57, no. 5 (2002): 2185-2221.

Ekkayokkaya, Manapol, Phil Holmes, and Krishna Paudyal. "The Euro and the Changing Face of European Banking: Evidence from Mergers and Acquisitions." European Financial Management 15, no. 2 (2009): 451-76.

Focarelli, Dario, Fabio Panetta, and Carmelo Salleo. "Why Do Banks Merge?" Journal of Money, Credit, and Banking 34, no. 4 (2002): 1047-066. 
Francis, Bill B., Iftekhar Hasan, and Haizhi Wang. "Bank Consolidation and New Business Formation." Journal of Banking \& Finance 32, no. 8 (2008).

Fuller, Kathleen, Jeffry Netter, and Mike Stegemoller, 2002, What do returns to acquiring firms tell us? Evidence from firms that make many acquisitions, Journal of Finance 57.4, 1763-1793.

George, Thomas J., Gautam Kaul, and Mahendrarajah Nimalendran. "Trading volume and transaction costs in specialist markets." The Journal of Finance 49, no. 4 (1994): 1489-1505.

Hagendorff, Jens, Ignacio Hernando, Maria J. Nieto, and Larry D. Wall. "What Do Premiums Paid for Bank M\&As Reflect? The Case of the European Union." Journal of Banking \& Finance 36, no. 3 (2012): 749-59.

Hagendorff, Jens, and Kevin Keasey. "Post-merger strategy and performance: Evidence from the US and European banking industries." Accounting \& Finance 49, no. 4 (2009): 725-751.

Haggard, K. Stephen, John S. Howe, and Andrew A. Lynch. "Do baths muddy the waters or clear the air?" Journal of Accounting and Economics 59, no. 1 (2015): 105-117.

Healy, Paul M., and Krishna G. Palepu. "Information asymmetry, corporate disclosure, and the capital markets: A review of the empirical disclosure literature." Journal of Accounting and Economics 31, no. 1 (2001): 405-440.

Hernando, Ignacio, Maria J. Nieto, and Larry D. Wall. "Determinants of Domestic and CrossBorder Bank Acquisitions in the European Union." Journal of Banking \& Finance 33, no. 6 (2009): 1022-032.

Houston, Joel F., and Michael D. Ryngaert. "The Overall Gains from Large Bank Mergers." Journal of Banking \& Finance 18, no. 6 (1994): 1155-176.

Houston, Joel F, Christopher M James, and Michael D. Ryngaert. "Where Do Merger Gains Come From? Bank Mergers from the Perspective of Insiders and Outsiders." Journal of Financial Economics 60, no. 2-3 (2001): 285-331.

Kane, Edward J. "Incentives for Banking Megamergers: What Motives Might Regulators Infer from Event-Study Evidence?" Journal of Money, Credit and Banking 32 (2000): 671.

Kalay, Alon. "International Payout Policy, Information Asymmetry, and Agency Costs." Journal of Accounting Research 52, no. 2 (2014): 457-472.

Krinsky, Itzhak, and Jason Lee. "Earnings announcements and the components of the bid-ask spread." The Journal of Finance 51, no. 4 (1996): 1523-1535.

Kothari, Sabino P., Susan Shu, and Peter D. Wysocki. "Do managers withhold bad news?" Journal of Accounting Research 47, no. 1 (2009): 241-276. 
Kyle, Albert S., 1985, “Continuous auctions and insider trading,” Econometrica 53, 1315-1336.

Laamanen, Tomi, and Thomas Keil. "Performance of serial acquirers: Toward an acquisition program perspective." Strategic Management Journal 29, no. 6 (2008): 663-672.

Linder, Jane C., and Dwight B. Crane, 1993, "Bank Mergers: Integration and Profitability”, Journal of Financial Services Research 7, 35-55.

Lepetit, Laetitia, Stéphanie Patry, and Philippe Rous. "Diversification versus Specialization: An Event Study of M\&As in the European Banking Industry." Applied Financial Economics 14, no. 9 (2004): 663-69.

Moeller, Sara B., Frederik Schlingemann, and René M. Stulz, 2004, Firm size and the gains from acquisitions, Journal of Financial Economics 73.2, 201-228.

Moeller, Sara B., Frederik Schlingemann, and René M. Stulz, 2005, Wealth destruction on a massive scale? A study of acquiring-firm returns in the recent merger wave, Journal of Finance 60, 757-782.

Neuhierl, Andreas, Anna Scherbina, and Bernd Schlusche. "Market reaction to corporate press releases." Journal of Financial and Quantitative Analysis 48, no. 04 (2013): 1207-1240.

Officer, Micah S., Annette B. Poulsen, and Mike Stegemoller. "Target-firm information asymmetry and acquirer returns." Review of Finance 13, no. 3 (2008): 467-493.

Piloff, Steven J., and Anthony M. Santomero. "The value effects of bank mergers and acquisitions." In Bank Mergers \& Acquisitions, pp. 59-78. Springer US, 1998.

Rhoades, Stephen A. "A summary of merger performance studies in banking, 1980-93, and an assessment of the operating performance and event study methodologies." Fed. Res. Bull. 80 (1994): 589.

Rhodes-Kropf, Matthew, and Steven Viswanathan. "Market valuation and merger waves." The Journal of Finance 59, no. 6 (2004): 2685-2718.

Reserve Board of Governors, Staff Study Number 167, July.

Roll, Richard. "The hubris hypothesis of corporate takeovers." Journal of Business (1986): 197216.

Schwert, G. W., 1996, "Markup Pricing in Mergers and Acquisitions," Journal of Financial Economics, 41, 153-192. 
Schwert, G. William. "Hostility in takeovers: In the eyes of the beholder?" The Journal of Finance 55, no. 6 (2000): 2599-2640.

Skinner, Douglas J. "Why firms voluntarily disclose bad news." Journal of Accounting Research 32, no. 1 (1994): 38-60.

Spiegel, Matthew, and Avanidhar Subrahmanyam. "Asymmetric information and news disclosure rules." Journal of Financial intermediation 9, no. 4 (2000): 363-403.

Sudarsanam, Sudi, Peter Holl, and Ayo Salami. "Shareholder wealth gains in mergers: effect of synergy and ownership structure." Journal of Business Finance \& Accounting 23, no. 5-6 (1996): 673-698.

Wittenberg-Moerman, Regina. "The role of information asymmetry and financial reporting quality in debt trading: Evidence from the secondary loan market." Journal of Accounting and Economics 46, no. 2 (2008): 240-260. 
Figure 1: Distribution of mergers through time

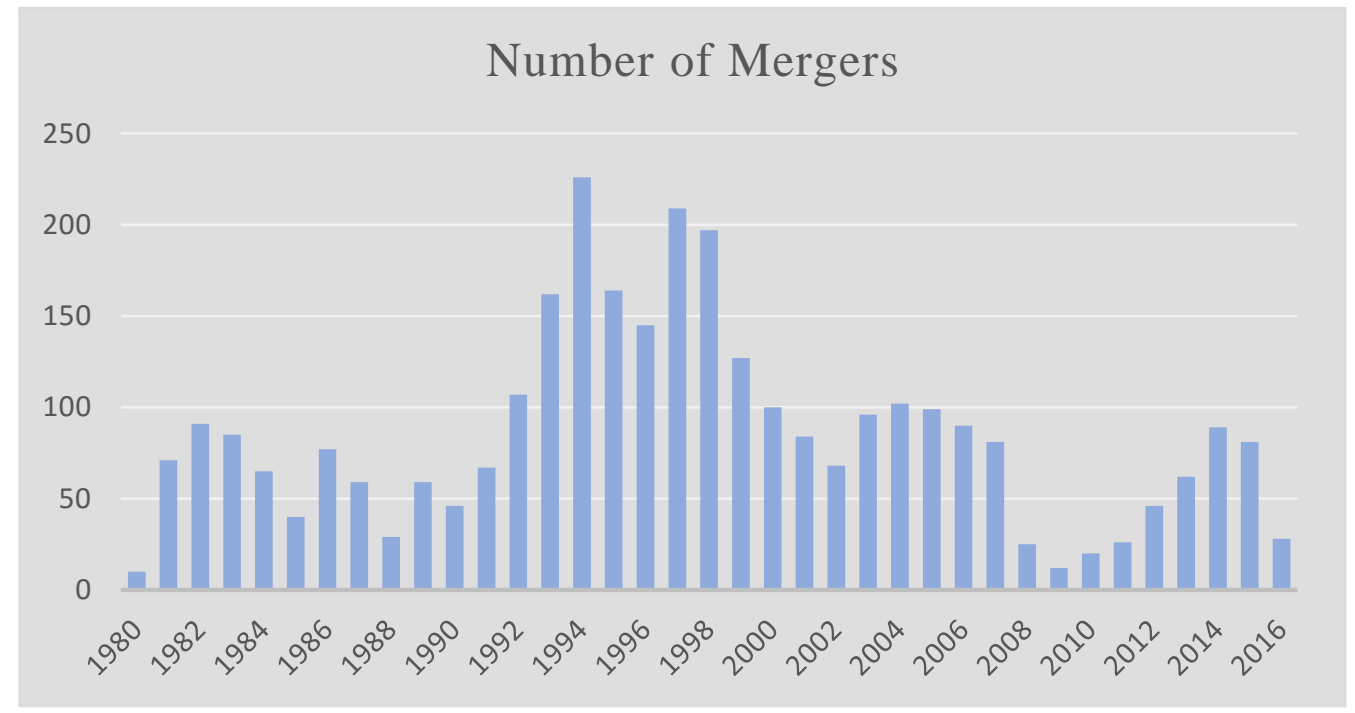

Figure 2: M\&A process

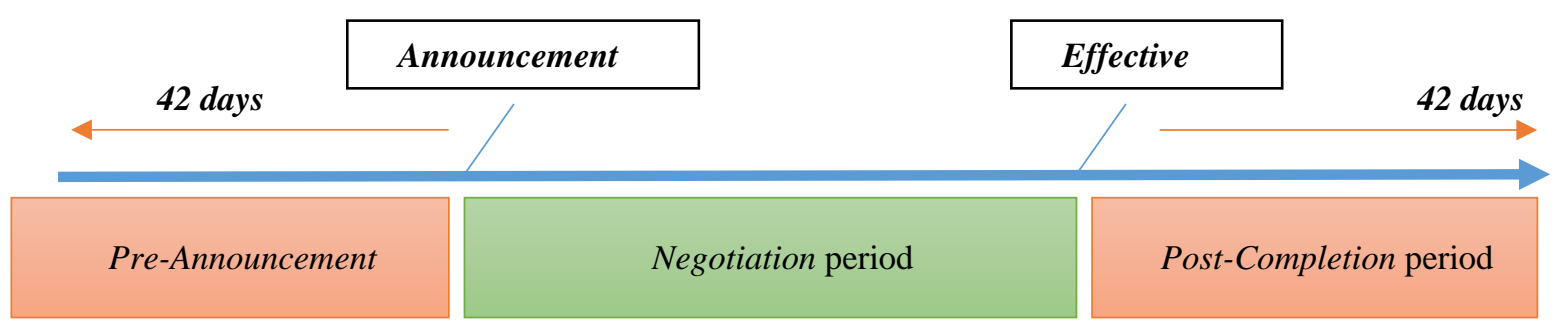




\section{Table 1 - Sample statistics}

Panel A reports the number of firm-year observations, the number of individual mergers, as well as the number of single acquirers. Panel B reports the characteristics of the deals. Panel C reports the summary statistics of the control variables per deal, and the information asymmetry measures on a firm-day basis, as percentages.

\begin{tabular}{|c|c|c|c|c|}
\hline \multicolumn{5}{|l|}{ Panel A: Full Sample } \\
\hline \multicolumn{2}{|l|}{ Firm-day observations } & \multicolumn{3}{|c|}{651,523} \\
\hline \multicolumn{2}{|l|}{ Pre-Announcement Period } & \multicolumn{2}{|r|}{130,251} & \\
\hline \multicolumn{2}{|l|}{ Negotiation Period } & \multicolumn{2}{|r|}{388,743} & \\
\hline \multicolumn{2}{|l|}{ Post-Completion Period } & \multicolumn{2}{|r|}{132,529} & \\
\hline \multicolumn{2}{|l|}{ Number of individual mergers } & \multicolumn{2}{|r|}{3,146} & \\
\hline \multicolumn{2}{|l|}{ Number of individual acquirers } & \multicolumn{2}{|r|}{582} & \\
\hline \multicolumn{5}{|l|}{ Panel B: Deal Characteristics } \\
\hline \multicolumn{2}{|l|}{ Target Status } & $\mathrm{N}$ & & Percent \\
\hline \multicolumn{2}{|l|}{ Mutual } & 9 & & 0.29 \\
\hline \multicolumn{2}{|l|}{ Private } & 1,440 & & 45.77 \\
\hline \multicolumn{2}{|l|}{ Public } & 1,424 & & 45.26 \\
\hline \multicolumn{2}{|l|}{ Subsidiary } & 273 & & 8.68 \\
\hline \multicolumn{5}{|l|}{ Deal Type } \\
\hline \multicolumn{2}{|l|}{ Acquisition of Assets } & 438 & & 13.92 \\
\hline \multicolumn{2}{|l|}{ Merger } & 2,708 & & 86.08 \\
\hline \multicolumn{5}{|l|}{ Deal Nature } \\
\hline \multicolumn{2}{|l|}{ Friendly } & 3,113 & & 98.95 \\
\hline \multicolumn{2}{|l|}{ Neutral/Hostile } & 33 & & 1.05 \\
\hline \multicolumn{5}{|l|}{ Method of Payment } \\
\hline \multicolumn{2}{|l|}{ All-Cash } & 467 & & 14.84 \\
\hline All-Stock & & 1,470 & & 46.73 \\
\hline Mixed & & 1,209 & & 38.43 \\
\hline Panel C: Summary Statistics & & & & \\
\hline Info. Asymmetry Measures & $N$ & Mean & Median & Std \\
\hline Turnover & 632,102 & 0.002 & 0.001 & 0.003 \\
\hline Amihud & 539,581 & 1.840 & 1.621 & 2.760 \\
\hline Daily Spread & 538,642 & 0.281 & 0.250 & 0.372 \\
\hline PQ Spread & 538,642 & 0.015 & 0.009 & 0.019 \\
\hline Effective Spread & 538,642 & 0.242 & 0.125 & 0.370 \\
\hline PE Spread & 538,642 & 0.009 & 0.004 & 0.014 \\
\hline HL Spread & 616,036 & 0.009 & 0.005 & 0.013 \\
\hline Roll & 538,642 & 0.391 & 0.250 & 0.497 \\
\hline Realized Volatility & 611,705 & 0.037 & 0.008 & 0.130 \\
\hline Std Returns & 632,102 & 0.002 & 0.001 & 0.003 \\
\hline Controls & & & & \\
\hline Total Assets ${ }_{t-1}$ & 3,146 & 24,560 & 4,641 & 113,244 \\
\hline Book to Market $t-1$ & 3,146 & 0.675 & 0.631 & 0.302 \\
\hline Debt to Equity $t-1$ & 3,146 & 1.718 & 1.407 & 1.299 \\
\hline Income Scaled $t-1$ & 3,146 & 0.012 & 0.012 & 0.005 \\
\hline
\end{tabular}


Table 2 - Information environment through the M\&A process

We estimate 10 daily proxies of information asymmetry following the method employed by Haggard, Howe and Lynch (2015), and Chordia et al., (2000) for a period of 42 days prior the announcement date of a merger and 42 days following the date the merger is effective. We then regress these monthly proxies on two indicator variables and controls as follows:

IAM $_{i, t}=\alpha_{i}+\beta_{1}$ Pre-Announcement Period $t+\beta_{2}$ Post-Date Effective Period $_{t}+\delta$ Controls $_{i, t}+\varepsilon_{i, t}$

Where Pre-Announcement Period equals 1 for all observations that occur before the announcement of the merger, 0 otherwise, and Post-Date Effective Period equals 1 for all observations that occur after the date the merger is effective, 0 otherwise. We include book to market, debt to equity, total assets and income scaled by lagged total assets as controls. We cluster all standard errors by firm and year-month. We do not report the coefficients on controls.

The following measures are used in accordance with Haggard et al. (2015) and Chordia et al., (2000). The coefficients of our market measures are reported in percent. Turnover is defined as the negative of the daily volume divided by shares outstanding. Amihud is the negative of the daily dollar volume price impact, defined as daily return divided by daily dollar volume, calculated in accordance with Amihud (2002). We calculate Daily Spread as the mean daily difference between the day's high and low trading price divided by the closing price. $P Q$ Spread is computed as the difference between the ask and bid price divided by half the ask plus the bid price. Effective Spread is calculated as twice the absolute value of the price minus the bid-ask midpoint. $P E$ Spread is computed as twice the absolute value of the price minus the bid-ask midpoint scaled by price. PQ Spread, Effective Spread and PE Spread are calculated in accordance with Chordia et al., (2000). HL Spread is the daily mean of the estimated effective spread calculated in accordance with Corwin and Shultz (2012). Roll is the daily estimated spread estimated by the covariance in prices calculated in accordance with Roll (1984). Realized Volatility is the squared daily returns. Standard Deviation is the monthly standard deviation of daily returns. For readability, all coefficients are scaled by a factor of 100

\begin{tabular}{|c|c|c|c|c|}
\hline & $\mathrm{N}$ & Pre-Announcement & Post-Completion & Adj. $R^{2}$ \\
\hline Turnover & 632,102 & $\begin{array}{c}\text { 0.006** } \\
(2.21)\end{array}$ & $\begin{array}{c}-0.024 * * * \\
(-6.90)\end{array}$ & $7.85 \%$ \\
\hline Amihud & 539,581 & $\begin{array}{l}-2.939 * \\
(-1.68)\end{array}$ & $\begin{array}{c}-8.078 * * * \\
(-4.59)\end{array}$ & $61.19 \%$ \\
\hline Daily Spread & 538,642 & $\begin{array}{l}-0.735 \\
(-1.60)\end{array}$ & $\begin{array}{c}-2.009 * * * \\
(-4.63)\end{array}$ & $5.10 \%$ \\
\hline PQ Spread & 538,642 & $\begin{array}{l}-0.033 \\
(-1.36)\end{array}$ & $\begin{array}{c}-0.101 * * * \\
(-4.51)\end{array}$ & $22.29 \%$ \\
\hline Effective Spread & 538,642 & $\begin{array}{l}-0.579 \\
(-1.42)\end{array}$ & $\begin{array}{c}-1.530 * * * \\
(-4.17)\end{array}$ & $5.59 \%$ \\
\hline PE Spread & 538,642 & $\begin{array}{c}-0.029 * * \\
(-2.21)\end{array}$ & $\begin{array}{c}-0.043^{* * *} \\
(-3.39)\end{array}$ & $14.31 \%$ \\
\hline HL Spread & 616,036 & $\begin{array}{l}-0.011 \\
(-0.97)\end{array}$ & $\begin{array}{l}-0.015 \\
(-1.35)\end{array}$ & $8.98 \%$ \\
\hline Roll & 538,642 & $\begin{array}{l}-0.734 \\
(-1.05)\end{array}$ & $\begin{array}{c}-2.827 * * * \\
(-4.31)\end{array}$ & $8.24 \%$ \\
\hline Realized Volatility & 651,448 & $\begin{array}{l}-0.001 \\
(-0.07)\end{array}$ & $\begin{array}{c}0.040 * * * \\
(3.96)\end{array}$ & $1.13 \%$ \\
\hline Return Std & 8,895 & $\begin{array}{c}-0.057 * * * \\
(-4.10)\end{array}$ & $\begin{array}{l}0.003 \\
(0.23)\end{array}$ & $7.45 \%$ \\
\hline
\end{tabular}

T-statistics in parentheses. ${ }^{* *},{ }^{* *}$, and * denote significance of coefficients at the $1 \%, 5 \%$, and $10 \%$ levels, respectively 


\section{Table 3 - Target ownership status}

We separate our sample into 2 sub-samples: Public target and Private target, depending on the nature of the target ownership. We run the following model:

IAM $_{i, t}=\alpha_{i}+\beta_{1}$ Pre-Announcement Period $t+\beta_{2}$ Post-Date Effective Period $_{t}+\delta$ Controls $_{i, t}+\varepsilon_{i, t}$

Where Pre-Announcement Period equals 1 for all observations that occur before the announcement of the merger, 0 otherwise, and Post-Date Effective Period equals 1 for all observations that occur after the date the merger is effective, 0 otherwise. We include book to market, debt to equity, total assets and income scaled by lagged total assets as controls. We cluster all standard errors by firm and year-month. We do not report the coefficients on controls.

The following measures are used in accordance with Haggard et al. (2015) and Chordia et al., (2000). The coefficients of our market measures are reported in percent. Turnover is defined as the negative of the daily volume divided by shares outstanding. Amihud is the negative of the daily dollar volume price impact, defined as daily return divided by daily dollar volume, calculated in accordance with Amihud (2002). We calculate Daily Spread as the mean daily difference between the day's high and low trading price divided by the closing price. PQ Spread is computed as the difference between the ask and bid price divided by half the ask plus the bid price. Effective Spread is calculated as twice the absolute value of the price minus the bid-ask midpoint. PE Spread is computed as twice the absolute value of the price minus the bid-ask midpoint scaled by price. PQ Spread, Effective Spread and PE Spread are calculated in accordance with Chordia et al., (2000). HL Spread is the daily mean of the estimated effective spread calculated in accordance with Corwin and Shultz (2012). Roll is the daily estimated spread estimated by the covariance in prices calculated in accordance with Roll (1984). Realized Volatility is the squared daily returns. Standard Deviation is the monthly standard deviation of daily returns. For readability, all coefficients are scaled by a factor of 100 .

\begin{tabular}{|c|c|c|c|c|}
\hline \multicolumn{5}{|c|}{ Panel A: Public target } \\
\hline & $\mathrm{N}$ & Pre-Announcement & Post-Completion & Adj. $R^{2}$ \\
\hline Turnover & 302,048 & $\begin{array}{c}0.024^{* * *} \\
(5.99)\end{array}$ & $\begin{array}{c}-0.029 * * * \\
(-4.91)\end{array}$ & $8.76 \%$ \\
\hline Amihud & 264,821 & $\begin{array}{l}2.952 \\
(1.27)\end{array}$ & $\begin{array}{c}-7.923 * * * \\
(-3.33)\end{array}$ & $65.09 \%$ \\
\hline Daily Spread & 265,753 & $\begin{array}{l}-0.141 \\
(-0.24)\end{array}$ & $\begin{array}{l}-0.891 \\
(-1.59)\end{array}$ & $9.63 \%$ \\
\hline PQ Spread & 265,753 & $\begin{array}{l}-0.028 \\
(-0.93)\end{array}$ & $\begin{array}{c}-0.074 * * * \\
(-2.78)\end{array}$ & $25.44 \%$ \\
\hline Effective Spread & 265,753 & $\begin{array}{l}0.308 \\
(0.52)\end{array}$ & $\begin{array}{c}-0.999 * * \\
(-2.02)\end{array}$ & $6.42 \%$ \\
\hline PE Spread & 265,753 & $\begin{array}{l}-0.015 \\
(-0.83)\end{array}$ & $\begin{array}{c}-0.035^{* *} \\
(-2.10)\end{array}$ & $14.58 \%$ \\
\hline HL Spread & 297,875 & $\begin{array}{l}-0.004 \\
(-0.26)\end{array}$ & $\begin{array}{l}0.006 \\
(0.44)\end{array}$ & $7.63 \%$ \\
\hline Roll & 265,753 & $\begin{array}{l}0.347 \\
(0.34)\end{array}$ & $\begin{array}{c}-2.313 * * \\
(-2.51)\end{array}$ & $4.35 \%$ \\
\hline Realized Volatility & 304,388 & $\begin{array}{c}0.000 \\
(-0.44)\end{array}$ & $\begin{array}{c}0.005^{* * *} \\
(3.64)\end{array}$ & $1.66 \%$ \\
\hline Return Std & 4,144 & $\begin{array}{c}-0.056 * * * \\
(-2.81)\end{array}$ & $\begin{array}{l}0.037 \\
(1.63)\end{array}$ & $7.75 \%$ \\
\hline
\end{tabular}

T-statistics in parentheses. ***, **, and * denote significance of coefficients at the $1 \%, 5 \%$, and $10 \%$ levels, respectively 
Table 3 - Continued

\begin{tabular}{|c|c|c|c|c|}
\hline \multicolumn{5}{|c|}{ Panel B: Private target } \\
\hline & $\mathrm{N}$ & Pre-Announcement & Post-Completion & Adj. $R^{2}$ \\
\hline Turnover & 276,926 & $\begin{array}{c}-0.012 * * * \\
(-3.11)\end{array}$ & $\begin{array}{c}-0.021^{* * *} \\
(-4.98)\end{array}$ & $5.32 \%$ \\
\hline Amihud & 229,870 & $\begin{array}{c}-12.229 * * * \\
(-4.33)\end{array}$ & $\begin{array}{c}-9.573 * * * \\
(-3.44)\end{array}$ & $52.41 \%$ \\
\hline Daily Spread & 228,562 & $\begin{array}{l}-0.557 \\
(-0.79)\end{array}$ & $\begin{array}{c}-2.015 * * * \\
(-2.98)\end{array}$ & $14.76 \%$ \\
\hline PQ Spread & 228,562 & $\begin{array}{l}-0.019 \\
(-0.49)\end{array}$ & $\begin{array}{c}-0.077^{* *} \\
(-2.15)\end{array}$ & $35.49 \%$ \\
\hline Effective Spread & 228,562 & $\begin{array}{c}-0.961 * \\
(-1.68)\end{array}$ & $\begin{array}{c}-1.457 * * \\
(-2.60)\end{array}$ & $9.79 \%$ \\
\hline PE Spread & 228,562 & $\begin{array}{c}-0.059 * * * \\
(-2.78)\end{array}$ & $\begin{array}{c}-0.067 * * * \\
(-3.20)\end{array}$ & $13.54 \%$ \\
\hline HL Spread & 265,973 & $\begin{array}{c}-0.031^{*} \\
(-1.65)\end{array}$ & $\begin{array}{c}-0.048 * * * \\
(-2.61)\end{array}$ & $11.00 \%$ \\
\hline Roll & 228,562 & $\begin{array}{c}-2.167 * * \\
(-2.01)\end{array}$ & $\begin{array}{c}-3.998 * * * \\
(-3.86)\end{array}$ & $13.22 \%$ \\
\hline Realized Volatility & 292,970 & $\begin{array}{l}-0.001 \\
(-0.55)\end{array}$ & $\begin{array}{l}0.001 \\
(0.68)\end{array}$ & $1.26 \%$ \\
\hline Return Std & 3,843 & $\begin{array}{l}-0.041^{*} \\
(-1.90) \\
\end{array}$ & $\begin{array}{c}-0.032 * \\
(-1.74)\end{array}$ & $14.24 \%$ \\
\hline \multicolumn{5}{|c|}{ Panel C: Subsidiaries } \\
\hline & $\mathrm{N}$ & Pre-Announcement & Post-Completion & Adj. $R^{2}$ \\
\hline Turnover & 50,552 & $\begin{array}{l}-0.001 \\
(-0.07)\end{array}$ & $\begin{array}{c}-0.027^{* *} \\
(-1.98)\end{array}$ & $7.93 \%$ \\
\hline Amihud & 42,884 & $\begin{array}{l}\text { 10.485* } \\
(1.79)\end{array}$ & $\begin{array}{l}-3.658 \\
(-0.64)\end{array}$ & $66.32 \%$ \\
\hline Daily Spread & 42,131 & $\begin{array}{l}-1.217 \\
(-0.94)\end{array}$ & $\begin{array}{l}-1.142 \\
(-0.98)\end{array}$ & $10.93 \%$ \\
\hline PQ Spread & 42,131 & $\begin{array}{l}-0.043 \\
(-0.61)\end{array}$ & $\begin{array}{l}-0.057 \\
(-0.85)\end{array}$ & $31.52 \%$ \\
\hline Effective Spread & 42,131 & $\begin{array}{l}-0.568 \\
(-0.56)\end{array}$ & $\begin{array}{l}-0.405 \\
(-0.41)\end{array}$ & $10.29 \%$ \\
\hline PE Spread & 42,131 & $\begin{array}{l}0.025 \\
(0.62)\end{array}$ & $\begin{array}{l}-0.006 \\
(-0.15)\end{array}$ & $13.77 \%$ \\
\hline HL Spread & 49,613 & $\begin{array}{l}0.035 \\
(0.98)\end{array}$ & $\begin{array}{l}0.029 \\
(0.81)\end{array}$ & $6.57 \%$ \\
\hline Roll & 42,131 & $\begin{array}{l}-0.581 \\
(-0.28)\end{array}$ & $\begin{array}{l}-1.366 \\
(-0.77)\end{array}$ & $12.88 \%$ \\
\hline Realized Volatility & 51,568 & $\begin{array}{l}0.006 * * \\
(2.44)\end{array}$ & $\begin{array}{l}0.007 \\
(1.61)\end{array}$ & $0.18 \%$ \\
\hline Turnover & 723 & $\begin{array}{l}-0.012 \\
(-0.27)\end{array}$ & $\begin{array}{l}-0.056 \\
(-1.21)\end{array}$ & $5.88 \%$ \\
\hline
\end{tabular}

T-statistics in parentheses. ***, **, and * denote significance of coefficients at the $1 \%, 5 \%$, and $10 \%$ levels, respectively 


\section{Table 4 - Deal form}

We separate our sample into 2 sub-samples: Merger (Panel B) and Acquisition of assets (Panel C), depending on the form of the deal. Panel A reports the type of target firms involved in both type of deals.

We run the following model:

$\mathrm{IAM}_{\mathrm{i}, \mathrm{t}}=\alpha_{\mathrm{i}}+\beta_{1}$ Pre-Announcement Period $\mathrm{t}+\beta_{2}$ Post-Date Effective Period $_{\mathrm{t}}+\delta$ Controls $_{\mathrm{i}, \mathrm{t}}+\varepsilon_{\mathrm{i}, \mathrm{t}}$

Where Pre-Announcement Period equals 1 for all observations that occur before the announcement of the merger, 0 otherwise, and Post-Date Effective Period equals 1 for all observations that occur after the date the merger is effective, 0 otherwise. We include book to market, debt to equity, total assets and income scaled by lagged total assets as controls. We cluster all standard errors by firm and year-month. We do not report the coefficients on controls.

The following measures are used in accordance with Haggard et al. (2015) and Chordia et al., (2000). The coefficients of our market measures are reported in percent. Turnover is defined as the negative of the daily volume divided by shares outstanding. Amihud is the negative of the daily dollar volume price impact, defined as daily return divided by daily dollar volume, calculated in accordance with Amihud (2002). We calculate Daily Spread as the mean daily difference between the day's high and low trading price divided by the closing price. PQ Spread is computed as the difference between the ask and bid price divided by half the ask plus the bid price. Effective Spread is calculated as twice the absolute value of the price minus the bid-ask midpoint. PE Spread is computed as twice the absolute value of the price minus the bid-ask midpoint scaled by price. PQ Spread, Effective Spread and PE Spread are calculated in accordance with Chordia et al., (2000). HL Spread is the daily mean of the estimated effective spread calculated in accordance with Corwin and Shultz (2012). Roll is the daily estimated spread estimated by the covariance in prices calculated in accordance with Roll (1984). Realized Volatility is the squared daily returns. Standard Deviation is the monthly standard deviation of daily returns. For readability, all coefficients are scaled by a factor of 100.

\begin{tabular}{lcccc}
\hline \multicolumn{2}{l}{ Panel A: Type of deal per target status } \\
\hline Deal Type / Target Status & \multicolumn{3}{c}{ Merger } & \multicolumn{2}{c}{ Acquisition of Assets } \\
\hline & Number & Percentage & Number & Percentage \\
Mutual & 9 & 0.33 & 0 & 0 \\
Private & 1,202 & 44.39 & 238 & 54.34 \\
Public & 1,409 & 52.03 & 15 & 3.42 \\
Subsidiary & 88 & 3.25 & 185 & 42.24 \\
& & & & 100 \\
Total & 2,708 & 100 & 438 & 100 \\
\hline
\end{tabular}


Table 4 - Continued

\begin{tabular}{|c|c|c|c|c|}
\hline \multicolumn{5}{|l|}{ Panel B: Mergers } \\
\hline & $\mathrm{N}$ & Pre-Announcement & Post-Completion & Adj. $R^{2}$ \\
\hline Turnover & 559,072 & $\begin{array}{c}0.008 * * \\
(2.79)\end{array}$ & $\begin{array}{c}-0.024 * * * \\
(-6.25)\end{array}$ & $7.92 \%$ \\
\hline Amihud & 477,365 & $\begin{array}{c}-4.812 * * \\
(-2.59)\end{array}$ & $\begin{array}{c}-8.311 * * * \\
(-4.42)\end{array}$ & $60.90 \%$ \\
\hline Daily Spread & 474,508 & $\begin{array}{l}-0.174 \\
(-0.37)\end{array}$ & $\begin{array}{c}-1.337 * * * \\
(-2.98)\end{array}$ & $12.06 \%$ \\
\hline PQ Spread & 474,508 & $\begin{array}{l}-0.029 \\
(-1.16)\end{array}$ & $\begin{array}{c}-0.082 * * * \\
(-3.66)\end{array}$ & $30.03 \%$ \\
\hline Effective Spread & 474,508 & $\begin{array}{l}-0.093 \\
(-0.21)\end{array}$ & $\begin{array}{c}-1.281 * * * \\
(-3.32)\end{array}$ & $8.37 \%$ \\
\hline PE Spread & 474,508 & $\begin{array}{c}-0.032 * * \\
(-2.22)\end{array}$ & $\begin{array}{c}-0.048 * * * \\
(-3.50)\end{array}$ & $14.65 \%$ \\
\hline HL Spread & 543,505 & $\begin{array}{l}-0.017 \\
(-1.45)\end{array}$ & $\begin{array}{l}-0.016 \\
(-1.38)\end{array}$ & $9.17 \%$ \\
\hline Roll & 474,508 & $\begin{array}{l}-0.611 \\
(-0.81)\end{array}$ & $\begin{array}{c}-2.991 * * * \\
(-4.23)\end{array}$ & $7.89 \%$ \\
\hline Realized Volatility & 577,775 & $\begin{array}{c}-0.003^{* * *} \\
(-6.38)\end{array}$ & $\begin{array}{c}-0.009 * * \\
(-2.15)\end{array}$ & $1.31 \%$ \\
\hline Return Std & 7,614 & $\begin{array}{c}-0.049 * * * \\
(-3.09)\end{array}$ & $\begin{array}{l}-0.006 \\
(-0.35)\end{array}$ & $9.15 \%$ \\
\hline \multicolumn{5}{|c|}{ Panel C: Acquisitions } \\
\hline & $\mathrm{N}$ & Pre-Announcement & Post-Completion & Adj. $\mathrm{R}^{2}$ \\
\hline Turnover & 73,030 & $\begin{array}{c}-0.01 \\
(-1.23)\end{array}$ & $\begin{array}{c}-0.029 * * * \\
(-3.35)\end{array}$ & $7.68 \%$ \\
\hline Amihud & 62,216 & $\begin{array}{l}7.384 \\
(1.56)\end{array}$ & $\begin{array}{l}-6.329 \\
(-1.37)\end{array}$ & $63.96 \%$ \\
\hline Daily Spread & 64,134 & $\begin{array}{c}-2.30 * * \\
(-2.25)\end{array}$ & $\begin{array}{l}-2.17 * * \\
(-2.12)\end{array}$ & $12.71 \%$ \\
\hline PQ Spread & 64,134 & $\begin{array}{c}-0.06 \\
(-1.01)\end{array}$ & $\begin{array}{l}-0.065 \\
(-1.02)\end{array}$ & $34.57 \%$ \\
\hline Effective Spread & 64,134 & $\begin{array}{l}-1.784 \\
(-2.24)\end{array}$ & $\begin{array}{l}-0.303 \\
(-0.35)\end{array}$ & $9.63 \%$ \\
\hline PE Spread & 64,134 & $\begin{array}{l}-0.037 \\
(-1.16)\end{array}$ & $\begin{array}{l}-0.033 \\
(-0.98)\end{array}$ & $12.56 \%$ \\
\hline HL Spread & 72,531 & $\begin{array}{l}0.004 \\
(0.13)\end{array}$ & $\begin{array}{l}-0.027 \\
(-0.82)\end{array}$ & $8.04 \%$ \\
\hline Roll & 64,134 & $\begin{array}{l}-2.669 \\
(-1.53)\end{array}$ & $\begin{array}{c}-3.063^{*} \\
(-1.74)\end{array}$ & $11.59 \%$ \\
\hline Realized Volatility & 73,727 & $\begin{array}{l}0.003 \\
(1.63)\end{array}$ & $\begin{array}{c}0.005 * * \\
(2.27)\end{array}$ & $0.21 \%$ \\
\hline Return Std & 1,094 & $\begin{array}{l}-0.016 \\
(-0.45)\end{array}$ & $\begin{array}{l}-0.021 \\
(-0.53)\end{array}$ & $9.62 \%$ \\
\hline
\end{tabular}

T-statistics in parentheses. ***, **, and * denote significance of coefficients at the $1 \%, 5 \%$, and $10 \%$ levels, respectively 


\section{Table 5 - Deal nature}

We look at the impact of hostile deals on the information environment. We run the following model: IAM $_{\mathrm{i}, \mathrm{t}}=\alpha_{\mathrm{i}}+\beta_{1}$ Pre-Announcement Period $\mathrm{t}_{\mathrm{t}}+\beta_{2}$ Post-Date Effective Period $_{\mathrm{t}}+\delta$ Controls $_{\mathrm{i}, \mathrm{t}}+\varepsilon_{\mathrm{i}, \mathrm{t}}$

Where Pre-Announcement Period equals 1 for all observations that occur before the announcement of the merger, 0 otherwise, and Post-Date Effective Period equals 1 for all observations that occur after the date the merger is effective, 0 otherwise. We include book to market, debt to equity, total assets and income scaled by lagged total assets as controls. We cluster all standard errors by firm and year-month. We do not report the coefficients on controls.

The following measures are used in accordance with Haggard et al. (2015) and Chordia et al., (2000). The coefficients of our market measures are reported in percent. Turnover is defined as the negative of the daily volume divided by shares outstanding. Amihud is the negative of the daily dollar volume price impact, defined as daily return divided by daily dollar volume, calculated in accordance with Amihud (2002). We calculate Daily Spread as the mean daily difference between the day's high and low trading price divided by the closing price. PQ Spread is computed as the difference between the ask and bid price divided by half the ask plus the bid price. Effective Spread is calculated as twice the absolute value of the price minus the bid-ask midpoint. PE Spread is computed as twice the absolute value of the price minus the bid-ask midpoint scaled by price. PQ Spread, Effective Spread and PE Spread are calculated in accordance with Chordia et al., (2000). HL Spread is the daily mean of the estimated effective spread calculated in accordance with Corwin and Shultz (2012). Roll is the daily estimated spread estimated by the covariance in prices calculated in accordance with Roll (1984). Realized Volatility is the squared daily returns. Standard Deviation is the monthly standard deviation of daily returns. For readability, all factors are scaled by a factor of 100.

\begin{tabular}{|c|c|c|c|c|}
\hline \multicolumn{5}{|l|}{ Hostile deals } \\
\hline & $\mathrm{N}$ & Pre-Announcement & Post-Completion & Adj. $R^{2}$ \\
\hline Turnover & 3,891 & $\begin{array}{c}-0.067^{*} \\
(-1.79)\end{array}$ & $\begin{array}{l}-0.036 \\
(-1.41)\end{array}$ & $17.79 \%$ \\
\hline Amihud & 3,351 & $\begin{array}{c}38.98 * * * \\
(3.48)\end{array}$ & $\begin{array}{c}31.98 * * * \\
(2.85)\end{array}$ & $75.55 \%$ \\
\hline Daily Spread & 2,103 & $\begin{array}{c}9.283^{* *} \\
(2.54)\end{array}$ & $\begin{array}{c}8.734^{* *} \\
(2.52)\end{array}$ & $34.13 \%$ \\
\hline PQ Spread & 2,103 & $\begin{array}{c}0.290 * \\
(1.67)\end{array}$ & $\begin{array}{l}0.263 \\
(1.56)\end{array}$ & $69.91 \%$ \\
\hline Effective Spread & 2,103 & $\begin{array}{c}5.760 * * * \\
(2.68)\end{array}$ & $\begin{array}{c}\text { 6.571*** } \\
(3.02)\end{array}$ & $25.12 \%$ \\
\hline PE Spread & 2,103 & $\begin{array}{c}\text { 0.216* } \\
(1.91)\end{array}$ & $\begin{array}{c}0.209^{* *} \\
(1.98)\end{array}$ & $38.75 \%$ \\
\hline HL Spread & 3,758 & $\begin{array}{c}0.292 * * * \\
(4.54)\end{array}$ & $\begin{array}{c}0.295 * * * \\
(3.37)\end{array}$ & $17.75 \%$ \\
\hline Roll & 2,103 & $\begin{array}{c}9.372^{* *} \\
(2.13)\end{array}$ & $\begin{array}{c}9.285^{* *} \\
(2.20)\end{array}$ & $49.07 \%$ \\
\hline Realized Volatility & 4,185 & $\begin{array}{c}0.01 * * * \\
(2.92)\end{array}$ & $\begin{array}{c}0.011 * * * \\
(2.99)\end{array}$ & $2.08 \%$ \\
\hline Return Std & 96 & $\begin{array}{l}-0.139 \\
(-0.93)\end{array}$ & $\begin{array}{l}-0.167 \\
(-1.09)\end{array}$ & $32.36 \%$ \\
\hline
\end{tabular}

T-statistics in parentheses. ***, **, and * denote significance of coefficients at the $1 \%, 5 \%$, and $10 \%$ levels, respectively 


\section{Table 6 - Method of payment}

We separate our sample into 2 sub-samples: All-cash acquisitions (Panel A) and All-stock acquisitions (Panel B), depending on the method of payment used to conclude the deal.

We run the following model:

$\mathrm{IAM}_{\mathrm{i}, \mathrm{t}}=\alpha_{\mathrm{i}}+\beta_{1}$ Pre-Announcement Period $\mathrm{t}+\beta_{2}$ Post-Date Effective Period $_{\mathrm{t}}+\delta$ Controls $_{\mathrm{i}, \mathrm{t}}+\varepsilon_{\mathrm{i}, \mathrm{t}}$

Where Pre-Announcement Period equals 1 for all observations that occur before the announcement of the merger, 0 otherwise, and Post-Date Effective Period equals 1 for all observations that occur after the date the merger is effective, 0 otherwise. We include book to market, debt to equity, total assets and income scaled by lagged total assets as controls. We cluster all standard errors by firm and year-month. We do not report the coefficients on controls.

The following measures are used in accordance with Haggard et al. (2015) and Chordia et al., (2000). The coefficients of our market measures are reported in percent. Turnover is defined as the negative of the daily volume divided by shares outstanding. Amihud is the negative of the daily dollar volume price impact, defined as daily return divided by daily dollar volume, calculated in accordance with Amihud (2002). We calculate Daily Spread as the mean daily difference between the day's high and low trading price divided by the closing price. PQ Spread is computed as the difference between the ask and bid price divided by half the ask plus the bid price. Effective Spread is calculated as twice the absolute value of the price minus the bid-ask midpoint. $P E$ Spread is computed as twice the absolute value of the price minus the bid-ask midpoint scaled by price. PQ Spread, Effective Spread and PE Spread are calculated in accordance with Chordia et al., (2000). HL Spread is the daily mean of the estimated effective spread calculated in accordance with Corwin and Shultz (2012). Roll is the daily estimated spread estimated by the covariance in prices calculated in accordance with Roll (1984). Realized Volatility is the squared daily returns. Standard Deviation is the monthly standard deviation of daily returns. For readability, all coefficients are scaled by a factor of 100.

\begin{tabular}{|c|c|c|c|c|}
\hline \multicolumn{5}{|c|}{ Panel A: All-Stock deals } \\
\hline & $\mathrm{N}$ & Pre-Announcement & Post-Completion & Adj. $R^{2}$ \\
\hline Turnover & 310,590 & $\begin{array}{c}0.010 * * \\
(2.49)\end{array}$ & $\begin{array}{c}-0.020 * * * \\
(-4.00)\end{array}$ & $9.06 \%$ \\
\hline Amihud & 304,348 & $\begin{array}{l}-5.860 \\
(-0.03)\end{array}$ & $\begin{array}{c}-248.99 * * \\
(-2.21)\end{array}$ & $2.36 \%$ \\
\hline Daily Spread & 285,270 & $\begin{array}{l}0.120 \\
(0.21)\end{array}$ & $\begin{array}{c}-1.324 * * \\
(-2.23)\end{array}$ & $10.00 \%$ \\
\hline PQ Spread & 285,270 & $\begin{array}{c}0.000 \\
(-0.01)\end{array}$ & $\begin{array}{c}-0.063 * * \\
(-2.07)\end{array}$ & $28.82 \%$ \\
\hline Effective Spread & 285,270 & $\begin{array}{l}0.156 \\
(0.31)\end{array}$ & $\begin{array}{c}-1.333^{* *} \\
(-2.83)\end{array}$ & $10.70 \%$ \\
\hline PE Spread & 285,270 & $\begin{array}{l}-0.003 \\
(-0.17)\end{array}$ & $\begin{array}{l}-0.023 \\
(-1.36)\end{array}$ & $18.37 \%$ \\
\hline HL Spread & 309,879 & $\begin{array}{l}-0.009 \\
(-0.57)\end{array}$ & $\begin{array}{l}-0.006 \\
(-0.38)\end{array}$ & $12.15 \%$ \\
\hline Roll & 285,270 & $\begin{array}{l}0.276 \\
(0.31)\end{array}$ & $\begin{array}{c}-2.283^{* * *} \\
(-2.64)\end{array}$ & $15.71 \%$ \\
\hline Realized Volatility & 310,585 & $\begin{array}{l}0.001 \\
(0.49)\end{array}$ & $\begin{array}{c}0.003^{* *} \\
(2.57)\end{array}$ & $1.74 \%$ \\
\hline Return Std & 4,223 & $\begin{array}{c}-0.06 * * \\
(-2.96)\end{array}$ & $\begin{array}{l}0.006 \\
(0.30)\end{array}$ & $11.48 \%$ \\
\hline
\end{tabular}


Table 6 - Continued

\begin{tabular}{|c|c|c|c|c|}
\hline \multicolumn{5}{|c|}{ Panel B: All-Cash deals } \\
\hline & $\mathrm{N}$ & Pre-Announcement & Post-Completion & Adj. $R^{2}$ \\
\hline Turnover & 87,934 & $\begin{array}{l}0.013^{*} \\
(1.78)\end{array}$ & $\begin{array}{l}-0.008 \\
(-0.95)\end{array}$ & $6.09 \%$ \\
\hline Amihud & 85,317 & $\begin{array}{l}17.541 \\
(1.20)\end{array}$ & $\begin{array}{l}4.818 \\
(0.40)\end{array}$ & $0.49 \%$ \\
\hline Daily Spread & 81,420 & $\begin{array}{c}-2.319 * * * \\
(-2.26)\end{array}$ & $\begin{array}{c}-3.275 * * * \\
(-3.22)\end{array}$ & $3.12 \%$ \\
\hline PQ Spread & 81,420 & $\begin{array}{l}-0.054 \\
(-0.91)\end{array}$ & $\begin{array}{l}-0.095 \\
(-1.56)\end{array}$ & $20.46 \%$ \\
\hline Effective Spread & 81,420 & $\begin{array}{c}-1.951^{* *} \\
(-2.32)\end{array}$ & $\begin{array}{c}-1.694 * * \\
(-1.96)\end{array}$ & $4.84 \%$ \\
\hline PE Spread & 81,420 & $\begin{array}{c}-0.058 * \\
(-1.86)\end{array}$ & $\begin{array}{c}-0.058 * \\
(-1.81)\end{array}$ & $12.64 \%$ \\
\hline HL Spread & 87,790 & $\begin{array}{c}-0.069 * * \\
(-2.32)\end{array}$ & $\begin{array}{c}-0.085 * * * \\
(-3.07)\end{array}$ & $8.51 \%$ \\
\hline Roll & 81,420 & $\begin{array}{c}-2.563^{*} \\
(-1.65)\end{array}$ & $\begin{array}{l}-2.97 * \\
(-1.85)\end{array}$ & $6.66 \%$ \\
\hline Realized Volatility & 87,927 & $\begin{array}{c}-0.003^{* *} \\
(-2.09)\end{array}$ & $\begin{array}{l}0.000 \\
(0.02)\end{array}$ & $0.95 \%$ \\
\hline Return Std & 1,288 & $\begin{array}{c}-0.096 * * * \\
(-3.12)\end{array}$ & $\begin{array}{l}-0.057 * \\
(-1.74)\end{array}$ & $10.84 \%$ \\
\hline
\end{tabular}




\section{Table 7 - Method of payment}

We observe the impact of the Dodd-Frank act on the information environment surrounding acquirers during the M\&A process. We use the following model:

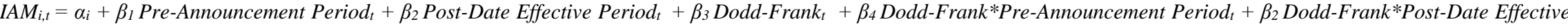
Period $_{t+}+\delta$ Controls $_{i, t}+\varepsilon i, t$

Where Pre-Announcement Period equals one for all observations that occur before the announcement of the merger, zero otherwise. Post-Date Effective Period equals one for all observations that occur after the date the merger is effective, zero otherwise. and Dodd-Frank an indicator variable equal to one if the observation occurs after the implementation of the Dodd-Frank Act on July 21 $1^{\text {st }}$ 2010, zero otherwise. We include book to market, debt to equity, total assets and income scaled by lagged total assets as controls. We cluster all standard errors by firm and year-month. We do not report the coefficients on controls. The following measures are used in accordance with Haggard et al. (2015) and Chordia et al., (2000). The coefficients of our market measures are reported in percent. Turnover is defined as the negative of the daily volume divided by shares outstanding. Amihud is the negative of the daily dollar volume price impact, defined as daily return divided by daily dollar volume, calculated in accordance with Amihud (2002). We calculate Daily Spread as the mean daily difference between the day's high and low trading price divided by the closing price. PQ Spread is computed as the difference between the ask and bid price divided by half the ask plus the bid price. Effective Spread is calculated as twice the absolute value of the price minus the bid-ask midpoint. $P E$ Spread is computed as twice the absolute value of the price minus the bid-ask midpoint scaled by price. PQ Spread, Effective Spread and PE Spread are calculated in accordance with Chordia et al., (2000). HL Spread is the daily mean of the estimated effective spread calculated in accordance with Corwin and Shultz (2012). Roll is the daily estimated spread estimated by the covariance in prices calculated in accordance with Roll (1984). Realized Volatility is the squared daily returns. Standard Deviation is the monthly standard deviation of daily returns.

\begin{tabular}{|c|c|c|c|c|c|c|c|c|}
\hline \multicolumn{9}{|l|}{ Dodd Frank Act } \\
\hline & $N$ & Pre-Announcement & Post-Completion & Dodd-Frank & Dodd-Frank*PA & Dodd-Frank*PC & $\begin{array}{c}\text { F-test } \\
D P A\end{array}$ & $\begin{array}{l}F \text {-test } \\
D P C\end{array}$ \\
\hline Turnover & 632,102 & $\begin{array}{l}0.001 \\
(0.34)\end{array}$ & $\begin{array}{c}-0.028 * * * \\
(-5.39)\end{array}$ & $\begin{array}{c}-0.197 * * * \\
(-8.29)\end{array}$ & $\begin{array}{c}0.065 * * * \\
(5.64)\end{array}$ & $\begin{array}{c}0.045 * * * \\
(5.17)\end{array}$ & $35.50 * * *$ & $5.44 * *$ \\
\hline Amihud & 539,581 & $\begin{array}{c}-3.562 * \\
(-1.72)\end{array}$ & $\begin{array}{c}-7.768 * * * \\
(-3.39)\end{array}$ & $\begin{array}{c}-85.007 * * * \\
(-8.51)\end{array}$ & $\begin{array}{c}13.704 * * * \\
(3.72)\end{array}$ & $\begin{array}{l}2.512 \\
(0.56)\end{array}$ & $9.90 * * *$ & 1.68 \\
\hline Daily Spread & 538,642 & $\begin{array}{l}-0.376 \\
(-0.71)\end{array}$ & $\begin{array}{c}-2.025 * * * \\
(-3.97)\end{array}$ & $\begin{array}{c}-27.981 * * * \\
(-14.94)\end{array}$ & $\begin{array}{l}0.393 \\
(0.63)\end{array}$ & $\begin{array}{c}1.719 * * * \\
(2.91)\end{array}$ & 0.00 & 0.95 \\
\hline PQ Spread & 538,642 & $\begin{array}{l}-0.012 \\
(-0.45)\end{array}$ & $\begin{array}{c}-0.100 * * * \\
(-3.67)\end{array}$ & $\begin{array}{c}-1.389 * * * \\
(-13.13)\end{array}$ & $\begin{array}{l}-0.011 \\
(-0.23)\end{array}$ & $\begin{array}{l}0.072 \\
(1.49)\end{array}$ & 0.32 & 0.46 \\
\hline Effective Spread & 538,642 & $\begin{array}{l}-0.257 \\
(-0.60)\end{array}$ & $\begin{array}{c}-1.521 * * * \\
(-3.88)\end{array}$ & $\begin{array}{c}-22.795 * * * \\
(-13.67)\end{array}$ & $\begin{array}{l}0.102 \\
(0.16)\end{array}$ & $\begin{array}{c}1.234^{* *} \\
(2.53)\end{array}$ & 0.19 & 0.48 \\
\hline PE Spread & 538,642 & $\begin{array}{c}-0.02 \\
(-1.40)\end{array}$ & $\begin{array}{c}-0.041 * * * \\
(-2.90)\end{array}$ & $\begin{array}{c}-0.833^{* * *} \\
(-14.49)\end{array}$ & $\begin{array}{l}0.022 \\
(0.78)\end{array}$ & $\begin{array}{c}0.03 \\
(1.07)\end{array}$ & 0.01 & 0.17 \\
\hline HL Spread & 616,036 & $\begin{array}{l}-0.006 \\
(-0.46)\end{array}$ & $\begin{array}{l}-0.012 \\
(-0.92)\end{array}$ & $\begin{array}{c}-0.334 * * * \\
(-6.99)\end{array}$ & $\begin{array}{l}-0.001 \\
(-0.03)\end{array}$ & $\begin{array}{l}0.001 \\
(0.06)\end{array}$ & 0.12 & 0.29 \\
\hline Roll & 538,642 & $\begin{array}{l}-0.129 \\
(-0.17)\end{array}$ & $\begin{array}{c}-2.807 * * * \\
(-3.79)\end{array}$ & $\begin{array}{c}-37.73 * * * \\
(-12.99)\end{array}$ & $\begin{array}{l}-0.369 \\
(-0.36)\end{array}$ & $\begin{array}{c}1.998 * * \\
(2.20)\end{array}$ & 0.83 & 1.79 \\
\hline Realized Volatility & 611,705 & $\begin{array}{l}0.001 \\
(0.97)\end{array}$ & $\begin{array}{c}0.004^{* * *} \\
(2.55)\end{array}$ & $\begin{array}{c}-0.016 * * * \\
(-4.22)\end{array}$ & $\begin{array}{l}-0.002 \\
(-1.03)\end{array}$ & $\begin{array}{c}-0.005^{* *} \\
(-2.58)\end{array}$ & 0.34 & 0.82 \\
\hline Return Std & 8,895 & $\begin{array}{c}-0.066 * * * \\
(-3.16)\end{array}$ & $\begin{array}{l}0.009 \\
(0.45)\end{array}$ & $\begin{array}{c}-0.296 * * * \\
(-4.79)\end{array}$ & $\begin{array}{c}0.08 \\
(1.48)\end{array}$ & $\begin{array}{l}-0.057 \\
(-1.55)\end{array}$ & 0.09 & 2.19 \\
\hline
\end{tabular}




\section{Appendix: Full literature review}

The successive waves of bank mergers in the 1980s and 1990s (see Figure 1) have been heavily scrutinized. The lifting of interstate regulation facilitated acquisitions in the banking industry, which over the years significantly reduced the number of commercial banks operating in the U.S. M\&As have been closely examined and discussed from multiple angles. From a motivation perspective, classic M\&A literature points to the various synergies resulting from an acquisition as the principal determinant of mergers. Multiple studies find that improvements can arise from better operational performance, a better use of the combined cash flows, tax savings, or more efficient management (Sudarsanam et al., 1996; Devos et al., 2009). The literature specific to the financial sector finds that synergies and diversification are the likely prime motivations for banks to undertake M\&As (Delong, 2001; Cornett et al., 2006).

Confronted with the finding that bidder claims of potential gains do not necessarily translate to significant observable improvements in performance (Piloff and Santomero, 1998; Berger et al., 1999), subsequent studies attempt to find other potential M\&A drivers. Brewer and Jagtiani (2007) find that the banks' desire to reach the status of “too big to fail” is another likely catalyst of the acquisition wave, as banks appear to be willing to pay a premium to realize acquisitions that would put them past a certain threshold. Kane’s (2000) findings are consistent with that result, further finding the notion that acquiring an in-state competitor leads to additional gains. Corvoisier and Gropp (2002) show that greater concentration tends to be beneficial to banks’ margins and acts as a counterweight to increased competition, which represents another incentive to acquire potential competitors. Finally, Draper and Paudyal (2008) find that banks that are undervalued may announce bids early in order to attract more 
attention, hoping for a stock price adjustment, thus pointing to visibility as another potential source of motivation.

Overall, the literature indicates that there might be additional incentives for banks to engage in sometimes costly M\&As beyond the traditional performance enhancement motives. Consequently, this multiplicity of potential drivers and incentives behind acquisitions points to the importance of information asymmetry between insiders (the negotiating parties) and outsiders (regulators, policy makers, and investors), an issue that we address in this paper.

Understanding the incentives behind a bank’s decision to make an acquisition is an important step, which naturally leads to the question of which firms are likely to be bidders’ targets. Hagendorff (2012) finds that acquiring firms tend to aim for high-growth, low-risk targets as potential prospects for acquisition. Hernando et. al (2009) document that poorly managed institutions are more likely to be the target of bidders, especially if synergies can be found. Attracted by the potential gains, acquirers then often restructure portfolios and loan policies in order to be more profitable (Focarelli et al., 2002).

The consequences of M\&As in the banking sector are widely debated, both from a performance efficiency angle as well as from a shareholder value perspective. DeYoung et al. (2009) observe that the literature is mixed, especially if we contrast findings that pertain to the US market compared to the EU market. Consistent with the hubris hypothesis (Roll, 1986), early studies of the US market do not yield evidence of banking industry M\&As creating value (Houston and Ryngaert, 1994; Piloff and Santomero, 1998).

Following studies show that bank mergers in general do not create any value, with some exceptions. For example, Delong, (2001) finds that mergers that aim at creating both activity- 
and geography-related synergies are an exception to the rule. Kane (2000) reaches a similar conclusion for mergers involving large US banking organizations becoming even more sizable.

Subsequent literature finds that bank M\&As actually create shareholder wealth. Attempting to disentangle mergers' consequences for both acquirer and target firms, Becher (2000) finds evidence that bank mergers in the 1990s created shareholder value. He shows that while acquiring firms break even, target firms usually witness large gains making the combined gain in value of the two firms positive. Houston et al. (2001) confirm these findings, showing that mergers slightly increase shareholder value if we combine the total value of the acquirer's and the target's stock, a result they attribute to the prospect of cost savings.

Performance is difficult to measure. Moller et al. (2004) find that smaller firms make significant gains around M\&A announcement as opposed to larger firms who, on average, see a significant decrease shareholder wealth. In a subsequent paper, Moller et al. (2005) find that mergers created value up until the mid-1990s, after which they became value-destroying. Dissecting returns on every deal, the authors conclude that if we exclude a few very large loss deals, mergers and acquisitions actually do create shareholder value.

More recent studies find that, overall, mergers tend to be beneficial to the target firm's shareholders, but value-destroying for the acquiring firm's shareholders (Al-Sharkas and Hassan, 2010; Al-Khasawneh and Essaddam, 2012). Studies of international banking also suggest that bank M\&As in the EU are value-creating (Lepetit et al., 2004). Cybo-Ottone and Murgia, (2000) find that EU bank mergers not only improve aggregate shareholder value, but they also improve value for both the target firm and the bidder. This finding is in contrast to the US and EU bank M\&As; the authors suggest that the difference is attributable to differences in 
regulation between the two markets, even though the development of the Eurozone appears to have curtailed that effect (Ekkayokkaya et al., 2009).

A similar pattern emerges regarding the performance efficiency of bank M\&As in that early studies find little or no gains of recently consolidated firms while recent studies document evidence of improvements. Indeed, initial investigations consistently suggest that mergers and acquisitions in the banking industry did not improve operating efficiency and were not costreducing (Berger and Humphrey, 1992; Linder and Crane, 1993; Rhoades, 1994). However, more recent studies showed that performance efficiency increases following M\&As, both in the US (Cornett et al., 2006) as well as the EU (Altunbas and Marques, 2008). Among them, Hagendorff and Vellascas (2011) show that to achieve better post M\&A efficiency, EU banks tend to cut costs and lending while US banks tend to undertake revenue enhancement activities.

The banking literature documents other direct effects of M\&As in the financial industry. Amidst these effects, multiple studies find evidence that external stakeholders might be affected negatively by bank consolidation. They show that acquiring firms offer higher loan prices (Carrow, 2006), and overall be less competitive vis-à-vis its customers following mergers (Corvoisier, 2002). Francis et al. (2008) also find that new business formation suffers following large M\&As, especially in the short term as larger consolidated banks tend to be more reluctant to supply credit to small business. Finally, recent studies show that following M\&As, the acquiring firms’ idiosyncratic risk decreases while their level of systematic risk increases thus raising questions about bank consolidations’ destabilization potential, the “concentration-fragility” hypothesis (Weiß et al., 2014; Elyasiani et al., 2015). 
However, to our knowledge no study looks at the effect of bank M\&As on information asymmetry. Information asymmetry has been shown to affect prices (Easley et al., 2002), cost of capital (Botosan, 1997), and trading volume (Atiase and Bamber, 1994; Krinsky and Lee, 1996). The accounting literature has extensively documented the effects of disclosure on information asymmetry between managers and investors (Spiegel and Subramanhyam, 2000; Core, 2001), and most especially investigated the release of bad news (Skinner, 1994; Healy and Palepu, 2001). Kothari et al. (2009) show that managers tend to withhold bad news until the point where they cannot withhold information anymore. Subsequent releases can trigger significant change in the information environment that managers might try to compensate by also revealing good news.

Another stream of the literature investigates the link between information asymmetry and various corporate events. Chae (2005) investigates the relationship between trading volume and information asymmetry. Looking at scheduled and unscheduled corporate events, she finds that information asymmetry changes around these events, and that the relation between trading volume and information asymmetry is inverse before scheduled announcement but direct after the announcement. This study shows that some events act as catalysts and trigger changes in information asymmetry and trading volume through the information that is released. It also confirms the possibility of a negative relationship between trading volume and the information environment. Since then, the literature has shown that some events and components of the firm also influence information asymmetry. Aboody and Lev (2000) argue that R\&D increases information asymmetry. More recently, Kalay (2014) shows that the information environment influences dividend payouts, while Haggard et al. (2015) show that accounting baths decrease 
information asymmetry. The cost and consequences associated with information asymmetry further motivate the study of the impact of M\&As on the information environment. 